\title{
Gastrin, cholecystokinin and gastrointestinal tract functions in mammals
}

\author{
P. Guilloteau ${ }^{1}$, V. Le Meuth-Metzinger ${ }^{2}$, J. Morisset $^{3}$ and R. Zabielski ${ }^{4}$ \\ ${ }^{1}$ INRA, Unité Mixte de Recherche - Système d'Elevage Nutrition Animale et Humaine (UMR SENAH), \\ Domaine de la Prise, 35590 Saint-Gilles, France \\ ${ }^{2}$ Université Paris 13, Faculté de Médecine, Laboratoire de Pharmacie Expérimentale et Clinique, \\ 93017 Bobigny cédex, France \\ ${ }^{3}$ Département Médecine, Faculté de Médecine, Université de Sherbrooke, Sherbrooke, Québec, J1H 5N4, Canada \\ ${ }^{4}$ Department of Physiological Sciences, Warsaw Agricultural University, 02-766 Warsaw, Poland
}

\begin{abstract}
The aim of the present review is to synthesise and summarise our recent knowledge on the involvement of cholecystokinin (CCK) and gastrin peptides and their receptors in the control of digestive functions and more generally their role in the field of nutrition in mammals. First, we examined the release of these peptides from the gut, focusing on their molecular forms, the factors regulating their release and the signalling pathways mediating their effects. Second, general physiological effects of CCK and gastrin peptides are described with regard to their specific receptors and the role of CCK on vagal mucosal afferent nerve activities. Local effects of CCK and gastrin in the gut are also reported, including gut development, gastrointestinal motility and control of pancreatic functions through vagal afferent pathways, including NO. Third, some examples of the intervention of the CCK and gastrin peptides are exposed in diseases, taking into account intervention of the classical receptor subtypes $\left(\mathrm{CCK}_{1}\right.$ and $\mathrm{CCK}_{2}$ receptors) and their heterodimerisation as well as CCK-C receptor subtype. Finally, applications and future challenges are suggested in the nutritional field (performances) and in therapy with regards to the molecular forms or in relation with the type of receptor as well as new techniques to be utilised in detection or in therapy of disease. In conclusion, the present review underlines recent developments in this field: CCK and gastrin peptides and their receptors are the key factor of nutritional aspects; a better understanding of the mechanisms involved may increase the efficiency of the nutritional functions and the treatment of abnormalities under pathological conditions.
\end{abstract}

\section{Nutrition: Gastrin: Cholecystokinin: Cholecystokinin-gastrin family receptors: Digestive} physiology: Digestive diseases

\section{Introduction}

In various fields under the label of nutrition and specifically in relation to growth, work played by the gastrointestinal (GI) tract (GIT) is the first physiological stage in animals and man and concerns the transformation of the diet into nutrients and then their absorption across the intestinal wall. All these phenomena are the consequences and/or the causes of many regulations. Most of them depend on a complex regulatory system more and more recognised as a unique system with different components including hormonal, nervous and immune (Besedovsky \& Rey, 1996; Guilloteau et al. 2002). The link in this unique system is composed of a number of substances which are supposed to translate and transduce the signals. It is frequently stated that the GIT represents 'the largest endocrine organ in the body' (Thompson et al. 1987). Indeed, more than 100 regulatory substances are released from the GI mucosa under a variety of conditions and from a variety of cells. Besides histamine and serotonin (important examples of non-peptide regulators), most of the other regulatory substances (often referred to as hormones) released by the enteroendocrine cells are peptides (Guilloteau \& Zabielski, 2005a). Among them,

\footnotetext{
Abbreviations: BBS, bombesin; $\mathrm{CCK}$, cholecystokinin; $\mathrm{CCK}_{1}$, receptor to gut peptides (CCK and gastrin) of type 1 (or A); $\mathrm{CCK}_{2}$, receptor to gut peptides (CCK and gastrin) of type 2 (or B or B/gastrin); CCKc, receptor to gastrin; CCK-C, receptor to gut peptides (CCK and gastrin) of type C or cancer; CNS, central nervous system; ECL, enterochromafin-like; GI, gastrointestinal; GIT, gastrointestinal tract; GPCR, G protein-coupled receptor; GRP, gastrin-releasing peptide; LCRF, luminal CCK-releasing factor; L-NNA, non-specific inhibitor of NO synthase; MMC, migating myoelectric complexes; NOS, NO synthase; OLETF, Otsuka Long-Evans Tokushima fatty.

* Corresponding author: Dr P. Guilloteau, fax +33 2234850 80, email Paul.Guilloteau@ rennes.inra.fr
} 
the gut regulatory peptides including the peptides of the cholecystokinin (CCK)-gastrin family, are considered as major substances which play a pivotal role in the digestive functions. Indeed, these gut-regulatory peptides are chemical messengers mostly implicated in the regulation of GI and pancreatic functions, including regulation of secretions, motility, absorption, digestion and cell proliferation. Moreover, peptides from this family share many of the same attributes, such as the presence of large precursor molecules, multiple active isoforms, and multiple and/or similar membrane-bound receptors.

In 1905, Edkins discovered gastrin, a substance produced by the stomach mucosa and implicated in the postprandial regulation of gastric acid secretion (Edkins, 1905). Gregory \& Tracy (1964), 60 years later, described as gastrins the two almost identical heptadecaspeptide amides, GI and GII, they had isolated from hog antral mucosa. Following a quarter of a century after gastrin discovery, Ivy \& Oldberg (1928) isolated a hormone from the intestine that contracts the gallbladder and relaxes the sphincter of Oddi, and named it cholecystokinin. Harper \& Raper (1943) isolated a hormone that stimulates pancreatic enzyme secretion and named it pancreozymin. Over 20 years later, Jorpes \& Mutt (1966) established that pancreozymin was the same substance as CCK. Moreover, later on it became evident that both regulatory substances did not totally fit into the classical hormonal definition as the other humoral substances act through blood circulation to induce specific biological effects in their target organs, since neurocrine, paracrine and luminocrine effects of CCK and/or gastrin have been reported (Konturek et al. 1986a, 2003b; Owyang, 1996; Deng \& Whitcomb, 1998). Therefore, it may be more proper to call gastrin and CCK gut-regulatory peptides (belonging to the $\mathrm{CCK}$-gastrin family of peptides) rather than hormones.

Kopin et al. (1992) and Wank et al. (1992) purified and cloned the gastrin and CCK receptors and then it became evident that the two peptides act on their target cells through a common class of seven transmembrane domain motif receptors. Gastrin and CCK, therefore, exert their biological and physiological effects on cells by binding to specific $G$ protein-coupled receptor (GPCR) subtypes. Receptors for the $\mathrm{CCK}$-gastrin family peptides have been classified into two subtypes (Kopin et al. 1992; Wank et al. 1992) on the basis of their affinities for a structurally and functionally related family of peptides with identical $\mathrm{COOH}$-terminal pentapeptide sequences, but with differences in sulfation at their sixth (gastrin) and seventh (CCK) tyrosyl residues, also with differences in their responses to specific antagonists (Jensen et al. 1989; Silvente-Poirot et al. 1993). The CCK 1 receptor binds to sulfated CCK at 500- to 1000-fold higher affinity than to gastrin, whereas the $\mathrm{CCK}_{2}$ receptor interacts with gastrin and CCK with almost the same affinity (Jensen et al. 1989). These two subtypes of receptors were previously called CCK-A and CCK-B (or CCK-B/gastrin), respectively, and they were renamed $\mathrm{CCK}_{1}$ and $\mathrm{CCK}_{2}$ receptors following the International Union of Pharmacology Committee on Receptor Nomenclature and Drug Classification (Vanhoutte et al. 1996; Noble et al. 1999). The main characteristics of these two major subtypes of CCK and gastrin receptors known until now have been well described along with the transduction mechanisms responsible for their message translation (Wank, 1995; Yassin, 1999; Fourmy et al. 2002; Miyasaka \& Funakoshi, 2003).

In the present review, we report recent knowledge on the involvement of $\mathrm{CCK}$ and gastrin in controlling digestive functions of the stomach, gut and pancreas, and particularly the interaction between nutrients and the two gut-regulatory peptide families. For this purpose, we have examined the release of $\mathrm{CCK}$ and gastrin peptides, paying special attention to paying their molecular forms and their specific receptors. Moreover, physiological and pathological effects are also described.

\section{Release of gastrin and cholecystokinin from the gastrointestinal tract}

Due to difficulties in purifying native CCK cells, little information is available on secretion of this peptide at the cellular level (Liddle, 1997) and the same is true for gastrin. For both peptides, the mechanisms responsible for their synthesis and their storage in their specific cells are well documented (Liddle, 1994; Walsh, 1994; Guilloteau et al. 2002; Schneider \& Sayegh, 2002; Rehfeld et al. 2003; Stepan et al. 2003; Varro \& Ardill, 2003), along with production of active peptides with several molecular forms.

\section{Molecular forms}

The complexity and molecular heterogeneity of the CCKgastrin family peptides have been revealed and it is now known that proCCK and progastrin, the two precursor molecules, are extensively processed into a wide variety of peptide products that are released from their cells of origin (Häkanson \& Rehfeld, 2002).

Gastrin. Gastrin is characterised by a pair of heptadecapeptide amides (gastrin with seventeen amino acid residues or G17) differing only in the presence or absence of a sulfate ester on a tyrosine residue at position 6 from the $\mathrm{COOH}$ terminus (Gregory \& Tracy, 1964). Later, $\mathrm{NH}_{2}$ terminally extended forms of $\mathrm{G} 17$, consisting of thirty-four amino acid residues (G34), were identified (Gregory \& Tracy, 1972). The major site of gastrin synthesis and secretion remains the gastrin-containing cell (G-cell) in the antropyloric mucosa. Other minor sites of production include the endocrine cells of the small intestine, the pancreas, the pituitaries and the extra-antral G-cells (Thomas et al. 2003). However, there are several peptides derived from the biosynthetic precursors of G17 and G34. The major products are the $\mathrm{COOH}$-terminal Gly-extended gastrins (i.e. the Gly-gastrins such as G34-Gly). Other small $\mathrm{COOH}$-terminal fragments of fourteen (G14 or mini gastrin) and six residues (G6) may occur in tissues (Gregory et al. 1979, 1983), but are not thought to be functionally important. In man, relatively small amounts of the $\mathrm{NH}_{2}$-terminally extended form of $\mathrm{G} 34$ may occur which is now known to correspond to a seventyone-residue peptide (Rehfeld \& Johnsen, 1994). A large form of gastrin originally named 'big big gastrin' is now thought to be an artifact. In man, the main circulating forms of gastrin are typically G17 and G34 (Varro \& Ardill, 2003). 
Cholecystokinin. CCK was first isolated as a thirty-threeamino acid peptide (CCK33), but CCK58 is the best characterised, larger form of biologically active CCK. All the other forms are proteolytic carboxy terminal fragments of CCK58. Thus, many other molecular forms are now known, including the CCK4, 8, 22, 39, 58 and 83 (Wank et al. 1992, 1994; Liddle, 1994, 2000). In human tissues and blood, CCK33, CCK8 and perhaps an intermediate form are the predominant forms of CCK (Liddle, 1997; Rehfeld, $1998 a, b)$. However, considerable debates continue regarding the abundance of CCK58 (Liddle, 2000). CCK is produced and secreted by I-cells within the mucosa of the small intestine. I-cells have not been shown to contain other gut hormones. Moreover, CCK is a member of the growing family of the 'brain-gut peptides'. Thus, CCK is one of the most abundant neuropeptides in the brain while gastrincontaining cells are very rare; $\mathrm{CCK}$ is also present in peripheral nerves (Liddle, 1994).

Factors affecting the production of molecular forms. The mammalian species is the first factor affecting molecular forms in blood. Thus, CCK8 and CCK22 are predominant in the pig whereas CCK33 and CCK58 are the major circulating forms in man (Liddle, 1994), dogs (Sun et al. 1992) and probably also in young calves (P Guilloteau and JA Chayvialle, unpublished results; Fig. 1). CCK58 is also the only endocrine form of CCK in the rat (Reeve et al. $2003 a$ ). The intestine is known to produce the larger molecular forms of the CCK-gastrin family peptides (which are characterised by longer half-lives than their shorter forms) than other organs, for example, the stomach, pancreas and central nervous system (CNS) (Guilloteau et al. 2002). For example, in the CNS, CCK8 is by far the most abundant peptide with larger forms present only in trace amounts in the brain (Rehfeld et al. 2003). In the human pyloric antral mucosa, the concentration of G17 is over 20-fold higher than that of G34, while in the duodenum G17 and G34 occur in similar proportions (Walsh, 1994). The number of I-cells are concentrated in the duodenum and proximal jejunum and decrease in number distally throughout the small intestine (Polak et al. 1975; Buffa et al. 1976; Larsson \& Rehfeld, 1978). Moreover, there are differential distributions of molecular forms along the small intestine. For example, in man and pigs, there is a marked change in ratios of CCK8:CCK33/39 down the intestine from 1:0.8 in human proximal jejunum to $1: 5.6$ in midintestine and from $1: 1.5$ in porcine distal jejunum to $1: 5.6$ in mid-intestine (Maton et al. 1984).

The respective proportions of G17 and G34 in the blood vary in different circumstances. For example in human subjects, G34 predominates in fasting plasma (Varro \& Ardill, 2003) and the three forms of CCK (CCK22, 33 and 58) are less abundant in the fasting state than postprandially (Rehfeld et al. 2003). In young calves fed milk replacer, the origin of dietary proteins modifies the production and profile of molecular forms in the blood. Thus, the ratios G34:G17 and CCK33:CCK22 were decreased in calves fed with nonclotting proteins in the stomach (whey powder) in comparison with those receiving clotting proteins (skimmed milk powder) since they were $2 \cdot 2-8 \cdot 0$ v. $1 \cdot 4-2 \cdot 0$ for immunoreactive gastrin and $1.2-2 \cdot 2$ v. $0.2-0.7$ for immunoreactive CCK (Guilloteau et al. 1994, 1997;
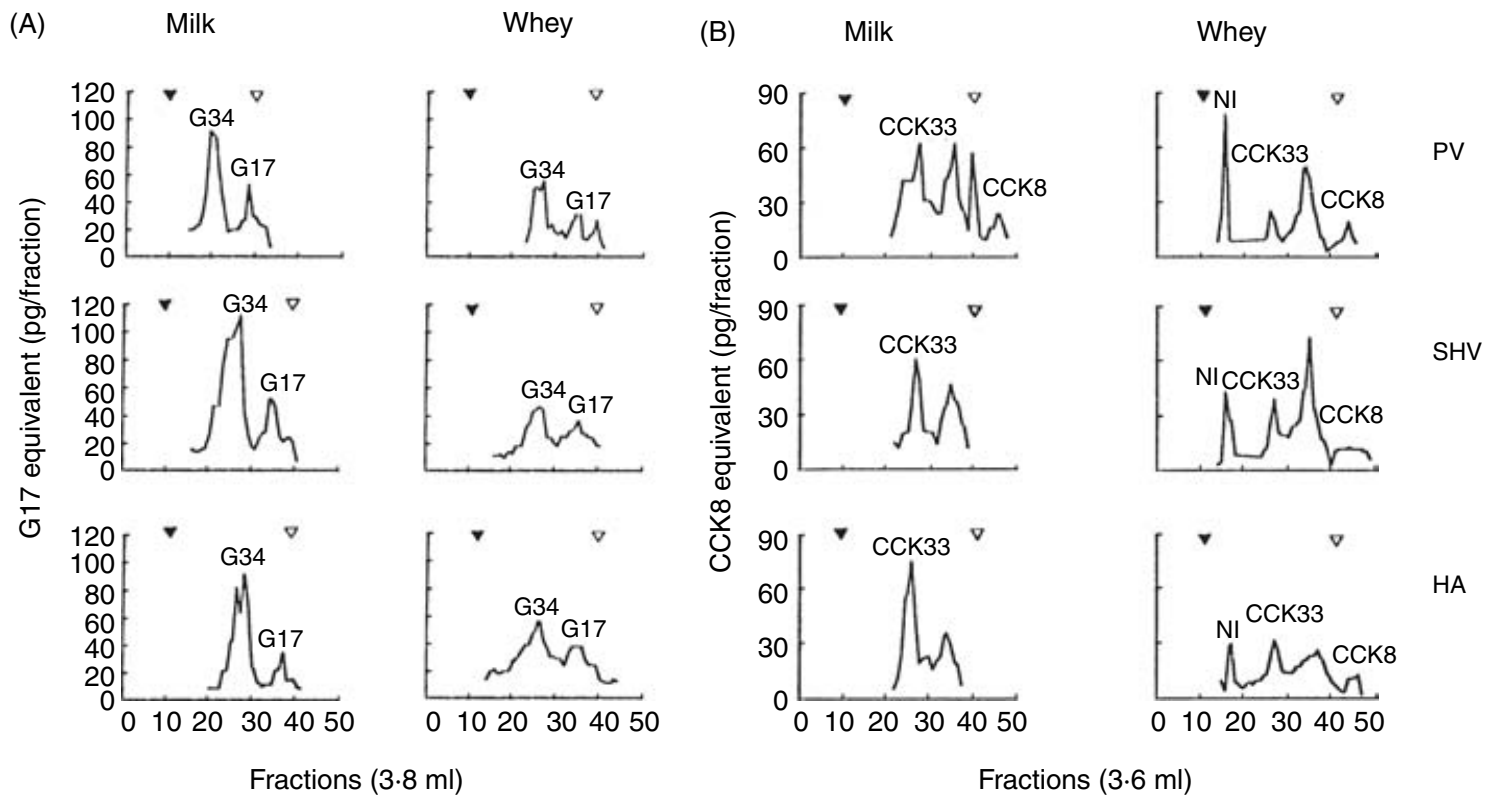

Fig. 1. Molecular forms of gastrin (A) and cholecystokinin (CCK) (B) in calves fed milk replacer, the protein of which was provided mainly by skimmed milk powder (milk) or whey powder (whey). Pooled calf plasma collected in either portal vein (PV) or sub-hepatic vein (SHV) or hepatic artery (HA) of six calves, 30 min after ingestion of milk, was analysed using gel chromatograthy on $1.5 \times 100 \mathrm{~cm}$ superfine G50 Sephadex columns run at $4^{\circ} \mathrm{C}, 10 \mathrm{ml} / \mathrm{h}$. Columns were calibrated with dextran blue (exclusion volume, about $40 \mathrm{ml}$ ), porcine CCK33, synthetic CCK8, non-sulfated human G34, non-sulfated human $\mathrm{G} 17$ and ${ }^{22} \mathrm{Na}$ (total volume, about $160 \mathrm{ml}$ ). For gastrin, $5 \mathrm{ml}$ of pooled calf plasma were supplied on the column. For CCK, $50 \mathrm{ml}$ of pooled plasma were concentrated on C18 Sep Pak cartridge (Waters). The retained phase was eluted with acetonitrile, dried under $\mathrm{N}_{2}$ and reconstituted in $5 \mathrm{ml}$ of elution buffer before application. NI, not identified. (P Guilloteau and JA Chayvialle, unpublished results). 
P Guilloteau and JA Chayvialle, unpublished results). In addition, these ratios vary in the general blood circulation (Fig. 1).

Globally, the metabolic clearance rate of the CCKgastrin family peptides is proportional to the size of the molecule (Thompson et al. 1987). For example, the rate of G34 is about five-fold lower than that of G17 (Walsh et al. 1974). The disappearance half-time $\left(T \frac{1}{2}\right)$ of the various molecular forms of exogenously infused gastrin has been reported in dogs: $1.8 \mathrm{~min}$ for minigastrin, $2.1 \mathrm{~min}$ for heptadecapeptide gastrin and $15 \mathrm{~min}$ for big gastrin (Walsh et al. 1974). Moreover, the disappearance half-life of endogenous CCK has been found to be $5-7 \mathrm{~min}$, but the half-time of exogenous CCK is between 2 and $3 \mathrm{~min}$ in both human subjects and dogs (Thompson et al. 1987). This means that the regulatory substances produced and secreted by the small intestine could act for a longer time for less produced peptide, giving the small bowel a relatively important role in regulation.

\section{Signalling pathways mediating the cholecystokinin-gastrin family peptide effects}

The I- and G-cells belong to a morphologically distinct population of epithelial cells which constitute the diffuse endocrine system in the GIT. The apical membrane of these cells contacts the luminal contents while the basal membrane is commonly thought to be a major site of regulatory peptide release into the bloodstream. Although gastrin and CCK were initially described as solely endocrine products, subsequent studies have shown that they can act in an autocrine or paracrine fashion to affect cellular functions. CCK may also serve as a transmitting agent for nervous impulses discharged into blood vessels after nervous stimulation in a true neurocrine fashion (Thomas et al. 2003).

Endocrine, autocrine and paracrine actions. Single or multiple forms of gastrin and $\mathrm{CCK}$ are produced from (pre)propeptides and secreted from peptide-producing cells into the interstitial fluid as well as in the blood (Walsh \& Dockray, 1994). From circulating blood, CCK and gastrin may specifically act on their target cells and/or organs to regulate the functions of the GIT, including the pancreas and gallbladder. The paracrine route for the action of these two hormones also has to be seriously considered as suggested by van der Schaar (2001) who observed in human subjects that a carbohydrate-rich meal with exogenous CCK did not induce gastric fundic relaxation, whereas a fat-rich meal without exogenous CCK did, despite similar plasma CCK levels. Moreover, they are interestingly implicated in the regulation of other physiological processes unrelated to digestive organ functions such as appetite regulation via the CNS and insulin secretion from pancreatic $\beta$-cells (Gibbs et al. 1973; Schonhoff et al. 2004).

Neurocrine actions. $\mathrm{CCK}$ is the most abundant neurotransmitter in the brain (Dockray, 1978) and coexists with dopamine in mesolimbic dopamine neurons (Crawley, 1991). CCK is produced by neurons of the brain as well as the peripheral nervous system of the GIT. Ultrastructural studies demonstrate that the CCK-producing cells are identical to I-cells of the human intestine. CCK neurons are found in the myenteric plexus, submucosa plexus and circular muscle layers of the distal intestine and colon. Postganglionic CCK nerve fibres are found in the pancreas surrounding the islets of Langerhans. Furthermore, although CCK has not been found in the intrinsic neurons of the stomach and duodenum, I-cells are in the celiac plexus and can be found in the vagus nerve, especially after injury (Thomas et al. 2003). Some $\mathrm{CCK}_{1}$ and $\mathrm{CCK}_{2}$ receptors have been identified in capsaicin-sensitive vagal afferent neurons (Kurosawa et al. 1997; Sternini et al. 1999). CCK $_{1}$ receptors appear to mediate the transmission of sensory information from the gut to the brain. CCK is released from the intestine after a meal and then activates $\mathrm{CCK}_{1}$ receptors on the vagus nerve in order to transmit sensations of fullness to the brain which subsequently terminates feeding behaviours (Kurosawa et al. 1997; Noble et al. 1999; Sternini et al. 1999) or GIT responses. Recently, the responses to intestinal lipids (chylomicron components) and proteins involving this neurohormonal pathway were documented in detail by Glatzle et al. (2003) and Darcel et al. (2005). In the same way, studying the stomach-brain communication in response to luminal acid backdiffusion, gastrin and gastric acid secretion, Danzer et al. (2003) have shown that, first, vagal afferents are stimulated by $\mathrm{CCK}$ and gastrin peptides acting on $\mathrm{CCK}_{1}$ receptors and, second, circulating gastrin can excite area postrema neurons that bear $\mathrm{CCK}_{2}$ receptors and project to the nucleus of the solitary tract, even if, to the best of our knowledge, gastrin has not been shown to be a neurotransmittor.

Luminal actions. In addition to their release into the circulation, there is growing evidence for CCK and gastrin release into the gut lumen. Indeed, gastrin was the first regulatory peptide to be detected in the lumen of the stomach in human subjects (Jordan \& Yip, 1972). CCK-like immunoactivity was also detected in the lumen of the small intestine, both under control conditions and following stimulation by feeding, perfusion of the duodenum with nutrients and electrical stimulation of the vagal nerve (Inoue et al. 1982; Zabielski et al. 1999). Sun et al. (1992) showed that $\mathrm{CCK}$ is present in the lumen of the canine duodenum in multiple molecular forms including CCK8, CCK33, CCK39 and CCK58 as the predominant one. Interestingly, this was not negligible 'leakage', but quite the reverse as considerable amounts of the fully active CCK were found in the gut lumen in comparison with the amount released into the bloodstream. No studies are available on the demonstration of CCK release into the gut lumen. However, Okumiya et al. (1996) demonstrated the release of gastrin from intestinal G-cells using immunoelectron microscopy. They observed changes of sub-cellular localisation of gastrin granules (massive migration from basal to apical region) as well as gastrin release into the small-intestinal lumen in an apocrine-like manner induced by carbachol. Without carbachol stimulation, gastrin granules were localised mostly in the basal region of the cell and released through the basal cell membrane. It remains unclear, however, whether under physiological conditions, mainly following stimulation of neuronal release of acetylcholine, 
that it would reproduce the results obtained with carbachol, though the effect of electrical stimulation of the vagal nerve in an anaesthetised calf study would suggest so (Zabielski et al. 1999). Nevertheless, these morphological data help to understand the route by which GI regulatory peptides may appear in the intestinal lumen and the interstitial space of the gut mucosa following stimulation. Moreover, $\mathrm{CCK}_{1}$ receptors were detected by immunochemistry in the intestinal mucosa and the blockade of these receptors resulted in a decrease in the pancreatic response to intraduodenal CCK (Zabielski et al. 1998b, 2002) and it is reasonable to assume that luminal CCK acts in physiological conditions.

Intestinal absorption of the peptides. The mechanism of absorption of luminally released CCK and gastrin is far from being understood, though an enterocyte transcellular pathway seems quite probable under physiological conditions rather than a paracellular process. In newborns, the canaliculo-vesicular system present in the enterocytes could be an ideal means of a non-specific transport of all large-size molecules, in particular during the first days of life when the so-called 'transport vacuoles' exist (Baintner, 2002). The contents of 'transport vacuoles' are not affected by the lysosomal enzymes, thereby the absorbed molecules retain their biological activity. Colostrum and milk bioactive polypeptides and proteins, including immunoglobulins, hormones, growth factors, etc, can be readily absorbed by this route. Until 3-4 weeks of life, the enterocytes of the neonate contain the 'digestive vacuoles' that may continue the process of macromolecule absorption, though, to our knowledge, it has not been demonstrated so far. Moreover, the vacuolated enterocytes that contain the digestive vacuoles are located in the lower two-thirds of the jejunum and in the ileum. In the young and adults, it seems probable that luminal CCK would permeate through the enterocyte lineage from the gut lumen to the interstitial fluid together with TAG, lipoproteins and other lymph constituents. Even regulatory peptides are at least in part hydrolysed by GI enzymes (Laster \& Walsh, 1968; Bunnett et al. 1988); Su et al. (2002) recently demonstrated that CCK8 can be absorbed through the GI membrane in the adult rat in a sitedependent manner. Moreover, the systemic availabilities of peptides given intraluminally can be significantly increased by preventing their degradation by the brush-border enzymes and their absorption is not limited by permeability. These results agree with those obtained by Glatzle et al. (2003) who had shown the presence of only small amount of CCK in the upper part of the rat mesenteric lymph duct (about 9 pM). Neither information on the CCK concentration in the interstitial fluid just behind the epithelial cell layer nor on the CCK hydrolysis in the mucosa and lymph is provided in their work.

\section{Factors regulating gastrin and cholecystokinin release}

In the present review, we will neither report on the aspects concerning the synthesis of the $\mathrm{CCK}$-gastrin family peptides nor the transduction system when the signal is transmitted as well as on factors implicated, since recently synthesis has been well documented at the genomic, molecular and cellular levels (Liddle, 1997; Dockray et al. 2001; Thomas et al. 2003; Dockray, 2004). The factors affecting peptide release can be linked to the animal or human subject itself or to its environment. We report here the effects measured by gastrin and CCK-specific RIA for total gastrin or CCK.

Animal species, digestive status and age. In singlestomached species, ingestion of food stimulates CCK and gastrin release; in ruminant species after the completion of weaning, no elevation of blood peptide concentrations is observed (Le Dréan et al. 1998). This phenomenon is, globally, due to the more regular stomach distension and the flow rate of digesta from the stomach to the duodenum as well as to the relative stability of $\mathrm{pH}$ of the duodenal content at about 2.75 during the preprandial and prandial phases. In preruminant calves, however, short-lasting variations in plasma CCK (but not in gastrin) in relation to the duodenal migrating myoelectric complexes (MMC) were observed. Feeding transiently affected the intestinal MMC and abolished CCK fluctuations. The fluctuations of plasma CCK in calves were apparently associated with the portions of coagulated milk that entered the duodenum from the abomasum, since the phenomenon was not observed in the calves fed milk formula which did not produce a clot in the abomasum (Zabielski et al. 1998a). In dogs, plasma CCK and gastrin did not show fluctuations in phase with duodenal MMC during the interdigestive period (Konturek et al. 1986b), indicating that fluctuations in plasma CCK are not related to the mechanism which generates the MMC, and are the result of stimulation by the digesta that pass the duodenum during phase II of MMC. In the rat, intact dietary proteins are effective stimulants of $\mathrm{CCK}$ release, but in canine and human species their digestion is required (Liddle, 1997). In the rat, ageing impairs CCK release, resulting in tissue accumulation and a decrease in the synthesis of CCK; however, that impaired release of central and peripheral $\mathrm{CCK}$ associated with ageing was observed in male rats, not in female rats (Ohta et al. 1995; Miyasaka et al. 1997a). In newborn rats, serum gastrin concentration was low, then it increased gradually until it peaked at about 2-3 weeks of age at the time of weaning (Ekelund et al. 1985). But gastrin is being produced in the newborn rat at the time when enterochromaffin-like (ECL) cells are few and a role for gastrin in initiating the development of these ECL cells has been studied (Björkqvist et al. 2002). In calves receiving milk replacer based on skimmed milk powder, plasma concentrations of gastrin decreased from 1 to 3 weeks of age, but this is reversed for CCK (Guilloteau et al. 1992a,b, 1997); after weaning, the basal and stimulated plasma concentrations of these two peptides increased (Toullec et al. 1992).

Moreover, it is suggested that CCK may modulate gastric leptin expression and secretion in pre-weaning milk-fed calves (Yonekura et al. 2002) as well as in rats (Brzozowski et al. 1999). Inversely, duodenal leptin stimulates CCK secretion and there is evidence for a positive leptin-CCK feedback loop (Guilmeau et al. 2003). Yonekura et al. (2002) also studied the effects of ageing and weaning on mRNA expression of the leptin and CCK receptors in the calf rumen and stomach. In the mucosa, the changes of CCK 
receptor mRNA expression (as well as that of leptin) coincided with ageing and changes in nutritional conditions. This is true particularly for the $\mathrm{CCK}_{1}$ receptor subtype in the rumen which is predomninant, whereas $\mathrm{CCK}_{2}$ receptor mRNA is scarcely expressed in the rumen of 3- and 13week-old animals. By contrast, in the stomach, $\mathrm{CCK}_{2}$ receptor transcription gradually decreased between 3 weeks of age and the adult stages but $\mathrm{CCK}_{1}$ receptor mRNA was expressed at very low level.

Meal, diet composition and digestive products. The release of CCK and gastrin is stimulated by the ingestion of a meal and its chemical composition in most singlestomached species (Liddle, 1997, 2000). For example, in human subjects, the basal blood levels of CCK are approximatively $1 \mathrm{pM}$ and increase to $5-10 \mathrm{pM}$ after a mixed meal (Liddle et al. 1985). Carbohydrates are the least potent stimuli of CCK release when compared with fat and protein (Liddle, 1997). Ethanol feeding in experimental animals and human subjects stimulates CCK secretion (Liddle et al. 1984). In the rat, it has been shown that it occurs by effecting on CCK-releasing factor (Saluja et al. 1997). In most of the species with a single stomach, the most active stimulants of CCK secretion are the digestion products of fat and protein (Brodish et al. 1994a,b). Hydrolysis of TAG to fatty acids with chain lengths of nine (or twelve) or more carbons results in effective CCK stimulation (Dockray et al. 2001). Among the amino acids, tryptophan and phenylalanine are the most potent stimuli in canine and human species. For gastrin, the well-recognised luminal stimuli are amino acids (particularly aromatic amino acids), dietary amines and Ca (Dockray et al. 2001). Moreover, intravenous infusion of amino acids stimulates CCK secretion (Liddle, 1997, 2000). In the rat, food restriction induces a reduction of pancreatic function (decrease of amylase secretion) by a mechanism that evidently involves a decrease of CCK release and a down regulation of the CCK receptors (reduction of CCK receptor affinity and capacity) (Chowdhury \& Rayford, 2001); these data suggest that CCK plays an important physiological role in adaptation of eating less food and thereby to a lowering of body size in rats and possibly in other mammals. In calves fed milk replacer, when dietary proteins are mainly from soya products instead of skimmed milk powder, postfeeding patterns of plasma gastrin and CCK concentrations are similar but more emphasised with highest variations (250-275\% of basal values $v$. about 200) (Le Dréan et al. 1997). In these species, the modifications in the release of gastrin and CCK induced by the nature of the dietary proteins are related to the ability of these proteins to clot in the stomach and consequently to the pattern of gastric emptying (Le Huërou-Luron et al. 1998). Finally, the anatomy of the G- and I-cells, with their apical surface open to the lumen of the intestine, makes it so that food, digestive products or secretions (and perhaps CCK-releasing factors such as described later - monitor peptide and luminal CCKreleasing factor; LCRF) can interact directly with the cells producing regulatory peptides (Liddle, 2000).

Organ and digestive secretions. According to the distribution of the I-cells in the proximal $v$. distal gut, nutrients experimentally introduced into the stomach or into the proximal small intestine are more effective secretagogues than when administered into the distal part. Endogenous bile (or bile acids) exerts a tonic inhibition on CCK secretion (Koide et al. 1993). Gastrin release is suppressed by gastric acid which probably acts by releasing the paracrine inhibitor somatostatin (Walsh, 1994).

Pancreatic and gut epithelial peptides that release cholecystokinin. Substantial evidence has indicated that at least one mechanism causing CCK release involves endogenously produced releasing factors that are secreted into the lumen of the intestine and under the proper conditions to stimulate CCK secretion ( $\mathrm{Lu}$ et al. 1989; Miyasaka et al. 1989; Spannagel et al. 1996; Wang et al. 2002). There is now strong evidence that a feedback mechanism exists in the chicken, pig, rat, dog and man. The existence and description of at least two types of CCKreleasing factors have been reported (Liddle, 1997, 2000). One of these, LCRF, was isolated from rat intestinal washings, while the other, diazepam-binding inhibitor, was identified in porcine intestine. These CCK-releasing factors are of intestinal origin and are present in the gut under basal conditions. By contrast, another peptide, the monitor peptide, also known as pancreatic secretory trypsin inhibitor-I or PSTI-61, is produced by pancreatic acinar cells and is secreted into pancreatic juice where, upon reaching the intestine, it stimulates CCK release (Iwai et al. 1986; Liddle, 1997). These releasing factors appear to mediate negative-feedback regulation of CCK secretion and the mechanism by which LCRF affects I-cell function in human subjects was recently studied (Wang et al. 2002).

Neural factors. The regulation of CCK release by neural factors seems complicated when examined in vivo. The effect of vagal innervation on $\mathrm{CCK}$ release has been examined in vagotomised patients who demonstrated an exaggerated CCK response to a liquid meal (Hopman et al. $1984 a, b)$. However, it remains unclear whether vagal innervation directly regulates CCK secretion or it modifies release indirectly through effecting on other targets such as the pancreas or gallbladder (Hopman et al. 1987). Bombesin (BBS), a tetradecapeptide originally isolated from the skin of the frog, is analogous to mammalian gastrin-releasing factor (GRP). BBS or GRP and cholinergic agonists increase gastrin secretion and tachykinins inhibit the secretion (Varner et al. 1981; Hirschowitz \& Molina, 1983; Smith et al. 2004). GRP stimulates CCK release and I-cells possess its receptor (Kanayama \& Liddle, 1991; Snow et al. 1994); therefore, GRP-containing nerves in the mucosa may modulate CCK release. This substance also stimulates gastrin secretion from G-cells (Seensalu et al. 1997).

Other regulatory substances. In man, loparemide, a peripherally acting opiate receptor agonist, enhances postprandial CCK secretion (Thimister et al. 1997) but the effects of other opiates and the exact site of action for stimulating CCK secretion remain unknown. BBS has been shown to directly stimulate CCK release (Snow et al. 1994). Several gastric peptides, such as apelin, proxenopsin and 
leptin have been shown to stimulate CCK release by classical pathways, as well as by the luminal way (Guilmeau et al. 2003; Wang et al. 2004). A recent study suggests that leptin does not act directly on the rat pancreatic acinar cells but inhibits the secretion of pancreatic enzymes indirectly via a neurohormonal CCK-vagal-dependent mechanism (Matyjek et al. 2003). Gastrin release is stimulated by BBS, GRP and inhibited by secretin, glucagon, gastric inhibitory polypeptide (GIP) and vasoactive inhibitory polypeptide (Thompson \& Marx, 1984). Moreover, somatostatin inhibits the synthesis and release of the peptides of the CCK-gastrin family. Somatostatin is considered as a hormone which terminates the prandial phase of gastric and pancreatic secretions. Finally, CCK inhibits gastrin secretion independently of paracrine somatostatin secretion (Schmidt et al. 2004). In patients infected with Helicobacter pylori, plasma gastrin concentrations are higher than in controls. Studies on the mechanisms implicated showed that in vivo cytokines, for example, IL-8 and inflammatory cells might mediate the effects of $H$. pylori infection on gastrin release (Lehmann et al. 1996; Beales et al. 1997). Reduced acid secretion caused by $H$. pylori also contributes to the hypergastrinaemia (Levi et al. 1989).

\section{Physiological effects of gastrin and cholecystokinin}

The cellular and molecular mechanisms by which gastrin and CCK act on the target cells are well described in original papers and reviews (Walsh \& Dockray, 1994; Greenly, 1999; Ikeda \& Fukuoka, 2003; Miyasaka \& Funakoshi, 2003; Prinz et al. 2003; Thomas et al. 2003; Dockray, 2004; Dockray et al. 2005). Briefly, gastrin or CCK peptide-stimulated signal transduction occurs with the binding of peptides to their cognate cell surface receptors, the GPCR $\left(\mathrm{CCK}_{1}\right.$ and $\mathrm{CCK}_{2}$ ). These receptors are characterised by an extracellular N-terminal segment, seven transmembrane $\alpha$-helices, three extracellular loops (exoloops), three cytoplasmic loops (cytoloops) and one C-terminal segment (Ji et al. 1998). It was originally thought that, for the occurance of GPCR signalling, specific interactions between the GI peptide and the receptor were necessary to produce conformational changes in the receptor and to stimulate intracellular signal transduction networks. However, recent studies suggest a more complex regulation of the GPCR through: (1) dimerisation with themselves (homodimerisation) and other receptors (heterodimerisation) (see pp. 270-271); (2) activation of differing $G$ proteins; (3) internalisation and desensitisation; (4) ability to change their conformation and interactions with empty or inactive receptors. It is suggested that this complex mechanism of regulation allows peptides to interact with GPCR, to stimulate diverse intracellular signalling pathways, and ultimately affect multiple physiological functions depending on cell types (Thomas et al. 2003). In this review, these mechanisms were not discussed but the receptor subtypes are taken into account to describe the effects of $\mathrm{CCK}$-gastrin family peptides through $\mathrm{CCK}_{1}$ or $\mathrm{CCK}_{2}$ receptors in physiological conditions as well as in the case of diseases (Table 1). Moreover, another class of receptor subtype, discovered by Yu et al. (1990) and more recently characterised (CCK-C receptor) (Biagini et al. 1997; Yassin, 1999) is also reported (Table 2).
Globally, control of satiety, gallbladder contraction, pancreatic exocrine secretion, gastrin, pepsinogen and leptin secretions, gastric emptying and gut motility are the best known actions of CCK which are mediated by $\mathrm{CCK}_{1}$ receptors (Silvente-Poirot et al. 1993; Bado et al. 1998; Wank, 1998). Action of CCK-gastrin family peptides which occur through the $\mathrm{CCK}_{2}$ receptors include modulation of anxiety and pain perception; this involves $\mathrm{CCK}_{2}$ receptors of the CNS (Crawley \& Corwin, 1994; Noble et al. 1999). The $\mathrm{CCK}_{2}$ receptor is also widely and abundantly expressed by cells in peripheral organs such as the stomach, the kidney and the pancreas where it mediates gastrin-stimulated gastric acid secretion, changes in renal $\mathrm{K}$ and $\mathrm{Na}$ absorption and glucagon secretion, respectively (Saillan-Barreau et al. 1999; Von Schrenck et al. 2000; Dockray et al. 2001; Lindström et al. 2001). CCK and gastrin also play a role in the control of cell proliferation, differentiation as well as in GI protection (Thompson \& Marx, 1984; Rehfeld \& van Solinge, 1994; Dockray et al. 2001; Trulsson et al. 2001; West \& Mercer, 2004). The peptides of the CCK-gastrin family have also indirect actions via the secretion of other regulatory substances. As an example, it was recently suggested that gastrin is a potential candidate for the postprandial decrease of ghrelin secretion in the rat (Lippl et al. 2004).

\section{Global effects of gastrin and cholecystokinin in the gut}

In this first part, some aspects on the effects of CCK on the activity of vagal mucosal afferent nerves are described. Then, we report on the physiological effects of the CCKgastrin family peptides through the $\mathrm{CCK}_{1}$ receptor pathway on the one hand and via the $\mathrm{CCK}_{2}$ receptors on the other hand.

Cholecystokinin affects the activity of vagal mucosal nerves. Low concentrations of CCK8 have been reported by Cottrell \& Iggo (1984) to excite vagal afferent receptors located in the mucosa of the proximal duodenum in sheep. Blackshaw \& Grundy (1990) have demonstrated in ferrets that close intra-arterial injection of CCK8 increases the electric discharge in single fibres originating from the gut segment where the hormone was applied. The CCKresponsive fibres were identified as the tension receptor afferents related to contractile activity as well as the mucosal receptor afferents with a conduction velocity in the $\mathrm{C}$-fibre range. The mucosal receptor afferents were localised in the stomach corpus and antrum but mostly in the duodenum, and could respond to low doses of CCK 8 but not to intraduodenal glucose, tryptophan or to distension. The responses of mucosal receptor afferents were enhanced by a mucolytic agent, acetylcysteine, which shortened the latency and increased the amplitude of responses, which were not affected, however, by cholinergic blockade with atropine and hexamethonium. Blackshaw \& Grundy (1990) concluded their study by suggesting that although activation of mucosal fibres from the gut by luminal stimuli has weak effects on vagal efferent fibre discharge, the reflexogenic potency may be enhanced if a large number of mucosal afferents would be stimulated simultaneously. Richards et al. (1996) provided further evidence in anaesthetised rats by showing that mesenteric nerve bundles contained one to two 
Table 1. Summary of the recent knowledge on the involvement of cholecystokinin (CCK)-gastrin family peptides and their receptors in the control of digestive functions and more generally their role in the field of nutrition in mammals, in physiological conditions

\begin{tabular}{|c|c|c|c|c|c|c|c|}
\hline \multirow[b]{2}{*}{ Origin of peptides } & \multirow[b]{2}{*}{$\begin{array}{l}\text { Receptor } \\
\text { subtypes }\end{array}$} & \multirow[b]{2}{*}{$\begin{array}{l}\text { Major molecular } \\
\text { forms }\end{array}$} & \multicolumn{5}{|c|}{ Site of action } \\
\hline & & & Gallbladder & Pancreas & Stomach & Small intestine & Large bowel \\
\hline & & \multicolumn{6}{|c|}{$\begin{array}{l}\text { NO: local action, mesenter vascular bed, blood flow } \\
\text { (via neural pathway) }\end{array}$} \\
\hline \multirow[t]{3}{*}{$\begin{array}{l}\text { G-cells (antrum, } \\
\text { small intestine) }\end{array}$} & $\mathrm{CCK}_{2}$ & G17, 34 & & Growth in fetus & $\begin{array}{l}\text { Growth } \\
\text { Parietal cells }(\mathrm{HCl}) \\
\text { ECL cells (histamine) } \\
\text { Distension }\end{array}$ & Growth & \\
\hline & & $\begin{array}{l}\text { Progastrin and biosynthetic } \\
\text { intermediates }\end{array}$ & & & Epithelial differentiation & & $\begin{array}{l}\text { Epithelial } \\
\text { proliferation }\end{array}$ \\
\hline & & Amidated gastrin & & & $\begin{array}{l}\text { Epithelial differentiation } \\
\text { and proliferation }\end{array}$ & & \\
\hline \multirow[t]{3}{*}{$\begin{array}{l}\text { I-cells (small } \\
\text { intestine, nerves) }\end{array}$} & $\mathrm{CCK}_{1}$ & CCK8, 33, 58 & Contraction & $\begin{array}{l}\text { Endocrine (insulin, PP, } \\
\text { glucagons) and exocrine } \\
\text { (enzymes) cells (via } \\
\text { neural pathways) }\end{array}$ & Somatostatin cells & Motility & \\
\hline & & & Gallstone & Growth & Gastric chief cells (leptin) & Mucosal immunity & \\
\hline & & & & $\begin{array}{l}\text { Blood circulation (exocrine } \\
\text { gland and islets, } \\
\text { insulinotropic and } \\
\text { vasodilatator effects) }\end{array}$ & $\begin{array}{l}\text { Gastric emptying and } \\
\text { motility } \\
\text { Gastroprotection } \\
\text { Mucus }\end{array}$ & $\begin{array}{l}\text { Growth and maturation } \\
\text { of small-intestinal } \\
\text { mucosa }\end{array}$ & \\
\hline
\end{tabular}


afferent fibres responding to CCK8 in a dose-related manner (threshold dose $<5 \mathrm{pmol}$ ), and that the administration of $\mathrm{CCK}_{1}$-receptor antagonist (devazepide) abolished an enhanced discharge in vagal afferent fibres induced by CCK8 application. The CCK-sensitive subpopulations of mesenteric afferent nerves slowly adapted to luminal hydrochloric acid and were not sensitive to intestinal distension. Luminal application of lignocaine transiently abolished the response to CCK, which further confirms the localisation of receptor afferents within the intestinal mucosa. Abdominal vagotomy eliminated the responses to CCK suggesting that the CCK-sensitive mucosal afferents exclusively follow the vagal pathway to the CNS to trigger various reflexes controlling behavioural and GIT effects involving inhibition of gastric motility and stimulation of pancreatic secretion. Consistently, studies in rats have indicated that intraduodenal sodium oleate, a major stimulator of pancreatic secretion, evoked the firing in the mucosal afferent fibres that could be abolished by the $\mathrm{CCK}_{1}$ receptor antagonist, devazepide (Lal et al. 2001).

The existence of CCK receptors in the gut mucosa suggested by electrophysiology recordings have been further supported by autoradiographic studies in rats by Lin \& Miller (1992) and Moriarty et al. (1997). Their competition studies using selective CCK ligands revealed that the vagal CCK receptors are heterogeneous. Accordingly, Miyasaka et al. (1996) have found expression of the $\mathrm{CCK}_{1}$ and $\mathrm{CCK}_{2}$ receptors' mRNA in the duodenal mucosa of the rat using the RT-PCR technique. More recently, an association of mucosal $\mathrm{CCK}_{1}$ and $\mathrm{CCK}_{2}$ receptors with neural components of the small intestine has been indicated in calves and rats using immunocytochemistry (Zabielski et al. 2002). The CCK receptors were localised in the intestinal villi within the lamina propria; however, little immunoreactivity could be observed close to the basal part of the enterocytes. In order to visualise the vagal sensory innervation of the gut, Berthoud et al. (1995) labelled the vagal afferents in vivo using injection of the lipophilic carbocyanine dye DiI into the nodose ganglion of rats. The DiI-labelled vagal afferent fibres were found with terminal arborisations mainly between the crypts and in the villous lamina propria. In both areas, vagal terminal branches came in close contact with the basal lamina, but did not appear to penetrate in it so as to make direct contact with epithelial cells or to penetrate between the epithelial cells into the lumen. The overall density of vagal afferent mucosal innervation was variable in their preparations. Many villi showed no evidence for such innervation while other areas had quite dense networks of arborising terminal fibres in several neighbouring villi. Using a similar approach, Berthoud \& Patterson (1996) examined the anatomical relationship between vagal afferents and I-cells in the rat small intestine. They demonstrated that the CCK immunoreactive cells were more abundant than vagal afferent fibres, and that both of them were present throughout the small intestine in the crypt and villi region. Most of the labelled vagal afferent axons distributed within the crypt and villous lamina propria were at distances of tens to hundreds of $\mu \mathrm{m}$ to the nearest CCK immunoreactive cell. Only a few of the CCK immunoreactive cells were in close $(<5 \mu \mathrm{m})$ anatomical contact with vagal afferent axons. These anatomical studies suggest that CCK released from the Icells may act on vagal sensory fibres in a paracrine fashion and help to understand the sense of the luminal release of CCK; since only some of the villi contain the sensory fibres for CCK, the release of CCK into the gut lumen might be a safe way (little biodegradation in the lumen) to spread the stimulus over a larger receptive area. Accordingly, the process of luminal CCK absorption by enterocytes may be an important link between the food and CCK-vagal mechanisms controlling GI function.

There is also growing evidence that gastrin may act through $\mathrm{CCK}_{2}$ receptors located on the vagal afferents. Moriarty et al. (1997) demonstrated by autoradiography approximately three-fold higher abundance of $\mathrm{CCK}_{1}$ receptors compared with $\mathrm{CCK}_{2}$ receptors, and no significant representation of CCK-C receptors on afferent fibres in the rat vagal nerve. They also demonstrated that $\mathrm{CCK}_{1}$ and $\mathrm{CCK}_{2}$ receptors are synthesised by nodose ganglion cells and that the receptor proteins are transported to the periphery along afferent fibres. Immunocytochemistry studies in rat and calf mucosa showed a co-localisation of $\mathrm{CCK}_{1}$ and $\mathrm{CCK}_{2}$ receptors with neural fibres (Zabielski et al. 2002). Our more recent studies in preruminant calves suggest that gastrin administrated into the duodenal lumen may stimulate the exocrine pancreas via $\mathrm{CCK}_{2}$ receptors localised on vagal afferents in the duodenal mucosa (Zabielski et al. 2004). Danzer et al. (2004) found that vagal afferents transmit physiological gastrin stimuli from the stomach to the brain stem in rats. Further studies on the involvement of vagal nerves would be helpful to define the mechanism more precisely.

Effects of the cholecystokinin-gastrin family peptides through cholecystokinin 1 receptor occupation on normal organs: secretion of pancreatic enzymes. From studies performed on isolated rat pancreatic acini, it was demonstrated that physiological concentrations of CCK caused amylase release (Wank, 1995), an effect totally blocked by the $\mathrm{CCK}_{1}$ receptor antagonist L-364,718 (Chang $\&$ Lotti, 1986). The potent secretagogue action of CCK was shown in healthy human subjects by increasing pancreatic lipase concentrations in duodenal fluid (Conwell et al. 2002). A similar action on dog pancreatic amylase secretion was also confirmed in vivo under constant CCK8 infusion, an effect also blocked by the specific $\mathrm{CCK}_{1}$ receptor antagonist L-364,718 (Hosotani et al. 1987). However, in man, pancreatic acini cells do not seem to respond directly to $\mathrm{CCK}_{1}$ and $\mathrm{CCK}_{2}$ receptor activation, and this is probably due to an insufficient level of receptor expression ( $\mathrm{Ji}$ et al. 2002). Moreover, it was recently shown in rodents that the isolated duck pancreatic acini possess both $\mathrm{CCK}_{1}$ and vasointestinal polypeptide-pituitary adenylate cyclaseactivating polypeptide receptors and that simultaneous activation of both is required for each to play a physiological role (Xiao \& Cui, 2004). The stimulatory effects of CCK and analogues on pancreatic enzyme secretion were also observed in guinea-pigs and mice and that are resulted from occupation of the $\mathrm{CCK}_{1}$ receptor (Sankaran et al. 1982; Jensen et al. 1989). Indeed, the presence of $\mathrm{CCK}_{1}$ receptor on rat and mouse pancreatic acinar cells was visualised by immunofluorescence with a specific $\mathrm{CCK}_{1}$ receptor 
antibody (Bourassa et al. 1999). In preruminant calves, the presence of $\mathrm{CCK}_{1}$ receptor was shown in the pancreas tissue (Le Meuth et al. 1993) and functional studies with the use of specific pharmacological $\mathrm{CCK}_{1}$ and $\mathrm{CCK}_{2}$ receptor antagonists indicated that endogenous $\mathrm{CCK}$ controls pancreas enzyme secretion via a direct action on the pancreatic acini as well as via a neurohormonal mechanism associated with the presence of CCK receptors on vagal afferent nerves in the duodenal mucosa (Zabielski et al. $1998 b, 2002,2004)$. The relative contribution of these mechanisms may depend on the stage of postnatal development of the duodenum and pancreas (Biernat et al. 1999). Studies in anaesthetised rats with CCK peptide and $\mathrm{CCK}_{1}$ receptor antagonists administrations showed similar results (Li \& Owyang, 1993, 1994), leading to a conclusion that in physiological conditions the prandial secretory response of the exocrine pancreas is chiefly driven by a neurohormonal mechanism, and a direct interaction of CCK with $\mathrm{CCK}_{1}$ receptor on pancreatic acini is just a pharmacological effect (Owyang, 1996).

Effects of the cholecystokinin-gastrin family peptides through cholecystokinin 1 receptor occupation on normal organs: secretion of islet hormones. CCK is also involved in endocrine pancreas secretion as it induces insulin secretion in vivo through $\mathrm{CCK}_{1}$ receptor occupation (Rosseti et al. 1987; Karlson \& Ahren, 1992). This regulatory peptide was also associated with pancreatic polypeptide release (Liddle et al. 1990) and possibly glucagon (Schweiger et al. 2000). These $\mathrm{CCK}_{1}$ receptors were indeed localised on islet cells (Bourassa et al. 1999) and more specifically on insulin and glucagon cells in at least seven different species (Morisset et al. 2003).

Effects of the cholecystokinin-gastrin family peptides through cholecystokinin 1 receptor occupation on normal organs: growth of the pancreas. CCK given in an amount that will induce plasma levels that are comparable with those following a meal induced enzyme secretion as well as growth of the rat pancreatic gland (Solomon et al. 1978) as indicated by significant increases in pancreatic weight, in total enzyme and protein contents as well as RNA and DNA (Solomon et al. 1983). This trophic action of CCK can be obtained whether CCK was exogenously administered (Solomon et al. 1983) or endogenously released either by feeding a high-protein diet (Morisset et al. 1992) or following pancreatic juice diversion (Rivard et al. 1991) and CCK exerts this trophic effect, not via a vagal afferent pathway, but directly on the pancreas, in vivo (Yamamoto et al. 2003). In each situation, the $\mathrm{CCK}_{1}$ receptor implicated as the response to $\mathrm{CCK}$ was abolished by the specific $\mathrm{CCK}_{1}$ receptor antagonist L-364,718 (Rivard et al. 1991; Morisset et al. 1992) Moreover, CCK and gastrin are implicated in the growth of the exocrine pancreas by causing hypertrophy and hyperplasia (Baldwin, 1995) and increasing DNA, RNA and the protein contents of rat pancreas (Johnson, 1981). Administration of CCK8 caused both increased proliferation and apoptosis in the pancreas. In the case of continuous administration of $\mathrm{CCK} 8$, the proliferation outweighs the apoptosis, causing hyperplasia, but, in the case of intermittent administration, the opposite effect was observed (Trulsson et al. 2001).
Effects of the cholecystokinin-gastrin family peptides through cholecystokinin 1 receptor occupation on normal organs: gallbladder contraction. $\mathrm{CCK}_{1}$ receptors were identified on human gallbladder smooth muscle and are responsible for the action of $\mathrm{CCK}$ in stimulating gallbladder contraction (Schjoldager et al. 1989), a physiological response blocked by the $\mathrm{CCK}_{1}$ receptor antagonist devazepide (Liddle et al. 1989). From CCK8 binding studies, the $\mathrm{CCK}_{1}$ receptor was also identified on human gallbladder muscles (Tang et al. 1996). Studies performed on dog gallbladder smooth muscle layers in vitro indicate that their contractions in response to CCK8 were atropine and tetradotoxin resistant, but completely eliminated by devazepide. However, postprandrial gallbladder contractions were partially inhibited by atropine and hexamethonium, and completely abolished by devazepide. These studies suggested that postprandial CCK-induced gallbladder contractions are controlled by $\mathrm{CCK}_{1}$ receptors both on the vagal nerve in stimulating endogenous acetylcholine release and on the gallbladder for stimulating muscle contraction (Sonobe et al. 1995). The relative contribution of these $\mathrm{CCK}_{1}$ receptors was elucidated in human subjects by Zhu et al. (2005), who found interactive relationships between the gallbladder motor function, plasma $\mathrm{CCK}$ and $\mathrm{CCK}_{2}$ receptor of gallbladders in patients with cholesterol stone disease. As a conclusion, these studies indicate that CCK affects gallbladder contractions chiefly in a hormonal manner, which is in contrast to a neurohormonal $\left(\mathrm{CCK}_{1}\right.$ and vagaldependent) mechanism dedicated to the exocrine pancreas.

Effects of the cholecystokinin-gastrin family peptides through cholecystokinin 2 receptor occupation on normal organs: secretion of pancreatic enzymes. The control of pancreatic enzyme secretion in rodents involves occupation of the $\mathrm{CCK}_{1}$ receptors on acinar cells as described earlier. However, the presence of these $\mathrm{CCK}_{1}$ receptors on pancreatic acinar cells of larger mammals has not yet been documented nor confirmed; at least, they were not found on calf, pig, horse and human acinar cells by immunofluorescence (Morisset et al. 2003). The presence of $\mathrm{CCK}_{2}$ receptors in the pancreas was firstly observed in the calf (Le Meuth et al. 1993; Desbois et al. 1999) and then in the pig (Philippe et al. 1997) by binding and photoaffinity labelling studies or by in situ hybridation and in man by storage phosphor autoradiography after radioligand binding to a tissue section (Tang et al. 1996). Similarly, amylase release from isolated pig acini in response to caerulein indicated stimulation in the nM range, a typical $\mathrm{CCK}_{2}$ response not inhibited by the $\mathrm{CCK}_{1}$ receptor antagonist MK-329 (Morisset et al. 1996). More recently, however, it was clearly demonstrated that freshly isolated human pancreatic acini neither release amylase in response to CCK8 nor to gastrin; a secretory response to carbachol was shown to document viability of the acini preparation as well as a response to $\mathrm{CCK} 8$ following $\mathrm{CCK}_{2}$ receptor transfection in these acini (Ji et al. 2001). To understand how pancreatic enzyme secretion is controlled by CCK in larger mammals and also possibly in rodents, future studies will have to focus on vagovagal reflex stimulation as elegantly described and documented by Konturek et al. (2003b) from an earlier observation that pancreatic enzyme secretion induced by 
CCK and secretin in human subjects was inhibited not only by the $\mathrm{CCK}_{1}$ receptor antagonist loxiglumide but also by atropine. It suggests that neuronal pathways play an important role in the action of CCK on pancreatic enzyme secretion (Gabryelewicz et al. 1990; Owyang, 1996) (see pp. 260-262).

Effects of the cholecystokinin-gastrin family peptides through cholecystokinin 2 receptor occupation on normal organs: growth of the pancreas. The factors regulating intra-uterine fetal growth of specific organs have remained largely unknown. The estimation that fetal pancreas contains between $2 \cdot 2$ and 4 ng of gastrin (Brand \& Fuller, 1988) and a majority of $\mathrm{CCK}_{2}$ receptors (Morisset et al. $2000 b$ ) lets us believe that this $\mathrm{CCK}_{2}$ receptor subtype could be involved in fetal pancreas development. From studies performed with a $\mathrm{CCK}_{2}$ receptor antagonist (Morisset et al. 1999) and gastrin immunoneutralisation (Feurle et al. 1995), both infused subcutaneously in the back of the dams for $28 \mathrm{~d}$, showed that gastrin was involved in fetal pancreatic organogenesis. It remains to be seen if these gastrin effects are confined to rodents' pancreas. However, after birth, gastrin mRNA expression and the hormone content disappeared in the rat pancreas (Morisset et al. 1999) and the $\mathrm{CCK}_{2}$ receptors remained on the endocrine $\Delta$ cells (Morisset et al. 2003); so it was not surprising to observe that postnatally, gastrin lost its trophic effect on the pancreatic gland as documented by many investigators (Chen et al. 1996). Recently, evidence was presented for heterodimerisation of type 1 and $2 \mathrm{CCK}$ receptors and that this complex can, once formed in transfected cells, become a powerful unit in promoting cell growth (Cheng et al. 2003). It is therefore believed that future studies on control of pancreas growth in large mammals should pay attention to this heterodimerisation phenomenon (see pp. 270-271) of the CCK receptors, now that we know that the pig pancreas can regenerate after pancreatectomy (Morisset et al. 2000a). In another way, whereas vagal hyperactivity itself stimulates cell proliferation of pancreatic $\beta$ - and acinar cells primarily through a cholinergic receptor in man (Kiba et al. 1996), it was recently shown that CCK exerts a trophic effect not via a vagal afferent pathway but directly on the pancreas in the rat (Yamamoto et al. 2003).

Effects of the cholecystokinin-gastrin family peptides through cholecystokinin 2 receptor occupation on normal organs: histamine release and hydrochloric acid secretion. Gastric acid secretion from the parietal cells is regulated by the enteric nervous system, the CNS, and neuroendocrine cells whose products act as autocrine and/or paracrine factors. Gastrin is primarily involved in stimulating ECL cells to secrete histamine via $\mathrm{CCK}_{2}$ receptor occupation (Roche et al. 1991; Bakke et al. 2001); it also seems to have a minimal effect on the parietal cells through the same $\mathrm{CCK}_{2}$ receptor (Schmidt \& Schmitz, 2004), even if no $\mathrm{CCK}_{2}$ receptor were evidenced on these cells (Bakke et al. 2001). From recent studies performed in gastrin $\mathrm{CCK}^{-1-}$ mice, it became clear that the major effect of CCK was to inhibit acid secretion by activating $\mathrm{CCK}_{1}$ receptors on somatostatin cells in the antral mucosa in order to inhibit gastrin release. In the oxyntic mucosa, CCK was shown to control histamine release (Chen et al. 2004). This mechanism was also demonstrated in the rat (Woltman \& Reidelberger, 1999; Lloyd et al. 1992, 2001), in sheep (Zavros \& Shulkes, 1997) and in man (Schmidt et al. 1994) via occupation of the $\mathrm{CCK}_{2}$ receptors present on the ECL cells (Modlin \& Tang, 1996).

Effects of the cholecystokinin-gastrin family peptides through cholecystokinin 2 receptor occupation on normal organs:leptin secretion. Leptin, the product of the ob gene, was initially identified in adipocytes (Zhang et al. 1994) and later in the stomach (Bado et al. 1998). Control of appetite and body-weight homeostasis are among its most important physiological functions. Leptin secretion was described under the control of gastrin through occupation of the $\mathrm{CCK}_{2}$ receptor (Attoub et al. 1999) as its release in plasma was significantly inhibited in vivo by the $\mathrm{CCK}_{2}$ receptor antagonist YM022. However, leptin was shown to be synthesised and secreted in canine gastric chief cells in response to CCK via the high-affinity state of the $\mathrm{CCK}_{1}$ receptors (Tsunoda et al. 2003). Furthermore, gastrin is also involved in leptin synthesis in mesenteric, epididymal and perirenal adipose tissues as it regulates the ob gene and, thus, control the expression of ob mRNA.

Results of cholecystokinin gastrin receptor occupation on normal organs. Gastrin can also bind to the $78 \mathrm{kDa}$ gastrin-binding protein, i.e. the so-called 'CCKc gastrin receptor' (Baldwin et al. 1986). It seems that this receptor subtype has been detected on isolated gastric parietal cells. CCKc receptor binds both amidated and non-amidated gastrins at a low affinity and is not related in structure to the classical CCK or gastrin receptors, and belongs to the family of enzymes involved in $\beta$-oxidation of fatty acids (Aly et al. 2004). CCKc receptors could also be expressed in a large proportion of glioma cells (Lefranc et al. 2003) but its role on these cells has not yet been characterised.

\section{Local effects of cholecystokinin and gastrin in the gut}

Gut development: maturation (remodelling of the gut mucosa) and growth. The trophic effects of plasma gastrin were initially demonstrated 30 years ago. Thus the trophic effects on the stomach and proximal small intestine are well documented but on the colon are not well established (FitzGerald et al. 2002) as well as in the oxyntic and duodenal mucosa (Johnson, 1976). In the developing rat (from fetal stage until weaning), the oxyntic mucosa would be under functional and trophic control of circulating gastrin and it was thought therefore that gastrin would play a role in the maturation and growth of the mucosa. This was particularly demonstrated after antrectomy in fetal sheep (Avila et al. 1989) following parenteral nutrition or oral ingestion in the rat (FitzGerald et al. 2002). But it was recently shown that gastrin affects neither the oxyntic mucosa nor the endocrine cells before weaning in rat stomach. After weaning, $\mathrm{CCK}_{2}$ receptor blockade is associated with a somewhat impaired development of the oxyntic mucosa and the ECL cells. While gastrin stimulation is of crucial importance for the onset of acid secretion during weaning and for the activation of ECL-cell 
histamine formation and secretion, the mucosa and ECLcell growth at this stage is only partly gastrin dependent. In contrast, the development of the ghrelin-producing A-like cells is independent of gastrin at all stages (Björkqvist et al. 2002). Gastrin is implicated in a marked proliferative action on the proximal small intestine which diminishes distally, but evidence for a trophic effect on the colon is very limited (FitzGerald et al. 2002; Thomas et al. 2003). CCK stimulates growth of the pancreas in experimental studies (Brants \& Morisset, 1976; Folsch et al. 1978). However, evidence for CCK playing a major role in the growth of the GI mucosa (stomach, small bowel and colon) is limited (Thomas et al. 2003). Gastrin administered directly into the lumen of the small intestine of rats produces trophic effects without changes in circulating gastrin (Johnson, 1981), but no effect was observed when gastrin was infused into the stomach, indicating no physiological role for luminal gastrin in the normal acid-secreting stomach. Following an intraduodenal $\mathrm{CCK}_{1}$ receptor antagonist, it was shown in the neonal calf that $\mathrm{CCK}$ controls the hyperplasic and hypertrophic development of the pancreas as well as the growth and maturation of the small-intestinal mucosa (mitotic index and depth of crypt, width and surface area of the villi, presence of empty vacuoles) (Biernat et al. 1999). Gastrin, as well as CCK, is present in relatively high concentrations in fetal gastric juice in calves (Guilloteau et al. 1998) and in sheep (Shulkes et al. 1984); gastrin in the lumen of the GIT may have a unique maturational role (Grand et al. 1976). But, recent studies indicate that the gastrin precursors and intermediates (progastrin and Glygastrin) are putative growth factors. Thus, preprogastrin gives a variety of products, each with a distinctive spectrum of biological activity. Progastrin itself stimulates colonic epithelial proliferation; biosynthetic intermediates (Gs-Gly) stimulate colonic epithelial proliferation and gastric epithelial differentiation; C-terminally amidated gastrins stimulate colonic proliferation, gastric epithelial proliferation and differentiation (acid-producing parietal cells and histamine-secreting ECL cells) (Dockray, 1999; Dockray et al. 2001). The rise in serum gastrin at weaning coincides with a rapid increase in the number and activity of the ECL cells and an increased thickness of the oxyntic mucosa (Björkqvist et al. 2002). Moreover, long-term hypergastrinaemia brings about ECL-cell hypertrophy and hyperplasia (Havu, 1986).

Gastrointestinal motility. Gastric emptying plays a key role in the regulation of food intake by controlling the flow of nutrients to their absorption sites in the small intestine. Among the many hormones and neuropeptides involved in the regulation of gastric emptying, CCK seems to play a prominent role in the early postprandial period, in postprandial CCK release and in the delay of gastric emptying (Olsson \& Holmgren, 2001; Leray et al. 2003). In healthy human subjects, the ingestion of fatty acids, which releases $\mathrm{CCK}$, reduces the volume of liquid delivered into the duodenum, primarily via a CCK-1 receptor-mediated delay in gastric emptying (Lal et al. 2004). Chronic nutritional disorders such as protein malnutrition are associated with delayed gastric emptying and increased postprandial plasma CCK levels. In rats adapted to a low-protein diet, gastric emptying was delayed whereas postprandial CCK levels were increased. A low-protein diet enhanced antral muscle contractile response to $\mathrm{CCK}$ and caerulein without altering response to acetylcholine. This increased contractility was associated with up regulation of $\mathrm{CCK}_{1}$ receptor mRNA levels in antral muscle. These data suggest that modulation of gastric emptying after adaptation to a low-protein diet involves up regulation of both $\mathrm{CCK}_{1}$ receptors and $\mathrm{CCK}$-induced contraction of antral smooth muscle (Leray et al. 2003). In male rats, oxytocin administration inhibits gastric emptying which occured concomitantly with an increase in plasma CCK concentrations. The results obtained suggest that $\mathrm{CCK}_{1}$, but not $\mathrm{CCK}_{2}$, receptors are involved in the mechanism and are consistent with the concept that oxytocin, in association with CCK, plays important roles in regulating gastric motility and food intake (Wu et al. 2002).

Moreover, CCK stimulates intestinal motility and gallbladder contractions (Niedereau \& Karaus, 1991; Morton et al. 2002; Krishnamurthy et al. 2003). But the action of CCK on GI motility is complex and dependent on many physiological factors (Romanski, 2004). The distance from the pylorus seems to be essential and an important difference in CCK action on duodenum, jejunum and ileum was observed. This can be caused by the variability in the smooth muscle CCK-receptor density along the small intestine, the spectrum of CCK action as neuropeptide (Sayegh \& Ritter, 2003), different hormonal regulation and up and down regulatory processes (Mawe, 1998; Noble et al. 1999). In young milk-fed calves, intraduodenal infusion of CCK9 increased the duration of phase II (irregular spiking activity) without any effect on the duration of phase I (no spiking activity) and III (regular spiking activity). Infusion of gastrin had no effect on duodenal MMC (Zabielski et al. 2004). In human subjects, Verkijk et al. (1998) studied the effect of gastrin on the small-intestinal MMC using antroduodenal manometry simultaneous with intraluminal acidity recording. Continuous infusion of gastrin-17 $(20 \mathrm{pmol} / \mathrm{kg})$ increased intragastric and intraduodenal acidity and suppressed phase II and phase III motor activity in both antrum and duodenum. Pharmacological block of gastric acid secretion completely antagonised the effect of gastrin on the MMC; thus the authors concluded that the effect of gastrin on interdigestive antroduodenal motility results from increased intraluminal acidity in human subjects.

Intervention of nitric oxide. $\mathrm{NO}$ is a messenger molecule that acts via the cellular cGMP pathway and is involved in several regulatory processes. Endogenous NO is generated mainly from the amino acid L-arginine, a process catalysed by NO synthases (NOS) which exists in two constitutive (endothelial NOS and neuronal NOS) and one inducible NOS isoform.

Intervention of nitric oxide: local blood flow. Konturek et al. (1993) were the first to demonstrate in fistulated dogs, with pancreatic blood flow measured by laser Doppler flowmetry, that endogenous NO affects pancreatic secretion through the changes in the vascular bed. They found that besides sham-feeding and meal feeding, continuous 
infusions of secretin plus CCK markedly induced pancreatic protein outputs. Infusion of a non-specific inhibitor of NOS (L-NNA) caused a profound inhibition of these secretions, whereas the addition of $\mathrm{L}$-arginine reversed this inhibition in part. NO did not affect basal or CCK-induced amylase release from isolated pancreatic acini. In anaesthetised dogs, infusion of NG-nitro-L-arginine caused a significant reduction in the pancreatic blood flow both while resting and following stimulation with secretin plus CCK but did not affect this flow in animals treated with glyceryl trinitrate. Addition of L-arginine attenuated the decrease in pancreatic blood flow and the increase in systemic blood pressure caused by L-NNA. The authors wrote that a considerable part of circulating CCK and secretin effects is related to vasodilatation produced by NO. Soon their results were confirmed in rat in vivo and in vitro studies (Konturek et al. 1994). In caerulein-induced acute pancreatitis, L-NNA significantly potentiated the inflammatory changes in the pancreas caused by caerulein in rats. Addition of L-arginine enhanced the pancreatic blood flow and ameliorated the pancreatitis induced by caerulein alone or that combined with L-NNA. Iwase et al. (2003) confirmed that exogenous CCK was a potent vasodilatator of exocrine as well as islet vasculature in the pancreas. Since both the insulinotropic and vasodilatating effects were totally absent in $\mathrm{CCK}_{1}$ receptor-null Otsuka Long-Evans Tokushima fatty (OLETF) rats, these effects were mediated through the $\mathrm{CCK}_{1}$ receptor. CCK mediates vasodilatation of the mesenteric vascular bed through the release of NO by neuronal NOS via its presynaptic $\mathrm{CCK}_{2}$ receptors, suggesting a neural mechanism by which CCK may increase mesenteric blood flow (Sanchez-Fernandez et al. 2004). Although CCK secreted posprandially from intestinal endocrine cells apparently stimulates pancreatic exocrine secretion and blood flow, the physiological significance of CCK action on islet blood flow is not clear yet. It is possible that the increased islet blood flow may facilitate the disposal of insulin to the target tissue after meals and by the way induce the insulo-acinar axis controlling the exocrine pancreas. In addition, since vagotomy affected basal fractional islet blood flow, the vagus nerve may regulate blood flow distribution within the pancreas (Iwase et al. 2003). NO is a potent vasodilator and has also been shown to play an important role in regulating the gastric mucosal microcirculation (Whittle, 1993).

Intervention of nitric oxide: pancreas growth and secretion. Trulsson et al. (2002), from an in vivo study in rats, demonstrated that endogenous $\mathrm{NO}$ production interacts with tissue homeostasis in the pancreas. Their studies on the exocrine pancreas indicate that endogenous NO formation reduces apoptosis both during basal conditions and during simultaneous stimulation with CCK8. Cell proliferation is stimulated by NO under basal conditions. In CCK-induced hyperplasia, NO inhibits the proliferation of acinar cells but stimulates the proliferation of ductal cells. Endogenous NO thus may have a regulatory role in the balance between proliferation and apoptosis in the exocrine pancreas. In a situation of strong growth stimulation by CCK8, NO seems to have a tonic inhibition of both cell synthesis and apoptosis, thus slowing down the acinar cell turnover in the pancreas. Further, during these conditions, NO seems to have a cell-type specific effect, different on acinar and ductal cell proliferation. Treatment of rat pancreatic acinar cells by CCK8 in vitro increases arginine conversion to citrulline as well as cGMP and activation of the L-arginine-NO pathway facilitates basal and stimulated pancreatic secretion in vivo (Trulsson et al. 2002).

Intervention of nitric oxide: motility. CCK activates specific enteric neuronal phenotypes in both the myenteric and the submucosal plexus. CCK activates NOS immunoreactive neurons which are probably inhibitory motor neurons in the myenteric plexus and putative intrinsic secretomotor and sensory neurons in the submucosal plexus (Sayegh \& Ritter, 2003). These results support a role for CCK in the integration of reflex control of intestinal motility and secretion via actions of both efferent and afferent components of intrinsic intestinal reflex arcs.

Intervention of nitric oxide: cytoprotection. CCK-induced gastroprotection and hyperaemia were mediated by increased release of NO (West et al. 2003) and it was suggested that constitutive isoforms of NOS were responsible for mediating $\mathrm{CCK}$-induced gastroprotection and hyperaemia. CCK and CCK secretagogues are potent gastroprotective agents against a variety of luminal irritants, particularly in response to a meal. CCK seems to exert its gastroprotective effects by increasing gastric mucosal blood flow. The mediator appears to be NO, and CCK increases NOS activity. However, basal levels of endogenous prostaglandins also appear to be necessary in order for CCK to fully exert its gastroprotective action (West \& Mercer, 2004). Endogenous gastrin is released by BBS and activates production of NO (West \& Mercer, 2005) through activation of constitutive NOS isoforms, and increased cyclo-oxygenase activity leads to increased production of prostaglandins. Thus, CCK8 (but also secretin, carbachol and PG E2) strongly stimulated mucus secretion from cultured rat gastric epithelial cells and gastrin stimulated it weakly (Tani et al. 2002). It seems likely that mucus secretion results from the existence of interaction among receptors (Tani et al. 2002).

In the case of pancreatic duct occlusion, Miyasaka \& Funokosi (2003) have found that the changes in the CCK content in the proximal intestine were correlated with increases and decreases in inflammation and then with regenerative change in the pancreas. In the case of cell injury processes of pancreatitis, CCK stimulates apoptosis and death-signalling pathways in rat pancreatic acinar cells, including caspase activation, cytochrome $\mathrm{c}$ release, and mitochondrial depolarisation (Gukovskaya et al. 2002). In rat gastric epithelial cancer cells, gastrin shows antiapoptotic activity through the up regulation of an active protein in the apoptosis processing and surviving (Konturek et al. 2003a).

Intervention of nitric oxide: defence-immune system. The GI system is innervated by the autonomous and the enteric nervous systems. Peptidergic nerve fibres are found in close approximation with immune cells of the GIT and evidence suggests an enteric nervous system influence on the body's 
immune response. GRP is released early in the digestive process to stimulate release of other neuropeptides such as CCK and gastrin. It was previously demonstrated that lack of enteral feeding with parenteral nutrition administration suppressed CCK secretion (Genton \& Kudsk, 2003). Parenteral nutrition with supplemental CCK, gastrin (or neurotensin) prevented most of the changes in relation to the gut-associated lymph tissue with this type of nutrition. This suggests that multiple hormone releases in response to feeding is necessary to preserve maximal mucosal immunity. Some neuropeptides, particularly CCK (GRP and neurotensin), appear promising to maintain mucosal immunity in patients who cannot receive enteral feeding during critical illness or after GIT loss (Genton \& Kudsk, 2003).

Control of pancreatic function through vagal afferent pathways. According to classical hormone theory, exogenous CCK evokes dose-dependent stimulation of pancreatic enzyme secretion. However, effective doses increase the concentration of $\mathrm{CCK}$ in the circulating blood to a level that cannot be achieved by any stimulation of endogenous CCK release. Thus, these effects have to be considered pharmacological. On the other hand, low doses of exogenous CCK (keeping the increase in the circulating blood within the physiological range) hardly affect pancreatic secretion and cannot convincingly explain its role in the regulation of pancreatic secretion. Moreover, stimulation with a low dose of CCK can be abolished by atropine or cold blockade of the vagal nerves, suggesting involvement of neural pathways. Magee \& Naruse (1983, 1988) explained this by an interplay between the nervous and hormonal regulation systems at the level of intrapancreatic nerves and ganglions. However, studies comparing the secretory responses to CCK8 administered into the general circulation or locally into a branch of the right gastroepiploic artery, which supplies the proximal duodenum (but not the pancreas), showed more pronounced responses following the intra-arterial infusions in both conscious and anaesthetised animals (Pierzynowski et al. 1991; Zabielski et al. 1991, 1994; Kiela et al. 1996). This led to the conclusion that the information driven by CCK must be switched into a neural mechanism before leaving the gut. This indirect mechanism agrees with the facts that amylase release from human pancreatic acinar cells is not mediated by either the $\mathrm{CCK}_{1}$ or $\mathrm{CCK}_{2}$ receptor in vitro (Miyasaka et al. 2002) and that the administration of antagonists of the $\mathrm{CCK}_{2}$ receptor does not totally inhibit the in vivo pancreatic response to a meal in the pig (Lhoste et al. 2002). Moreover, if we consider the classic hypothesis of hormonal action of CCK via the blood, we must keep in mind, first, that the blood plasma contains enzymes, endopeptidases and aminopeptidases, capable of deactivating CCK (Deschodt-Lanckman et al. 1983), and second, that the intestinal blood promptly transports these newly released gut peptides to the liver, an important site of gut peptide deactivation. It seems unlikely, therefore, that a message precisely generated in response to food or other local stimuli in the upper gut would be arbitrarily modified in the first pass by the liver and blood plasma enzymes well before reaching the exocrine pancreas.
In calves, intra-arterial infusion of CCK8 (10 and $100 \mathrm{pmol} / \mathrm{kg}$ body weight) induced secretion of pancreatic juice rich in enzymes, without affecting the concentration of CCK in the peripheral blood plasma (Zabielski et al. 1994). The intra-arterial stimulation was greater and had a shorter lag time than the respective intravenous stimulation. Cold blockade of vagal nerve conductivity in conscious calves diminished the effect of intra-arterial CCK8, and delayed and decreased the pancreatic response to intravenous $\mathrm{CCK} 8$, suggesting that vagal reflexes are particularly important in the local duodenal mechanism (Zabielski et al. 1994). In piglets, the intra-arterial infusion of a physiological-like dose of CCK8 (15 pmol/ $\mathrm{kg}$ body weight) stimulated pancreatic secretion while intravenous infusion was ineffective (Kiela et al. 1996). Participation of mucosal $\mathrm{CCK}_{1}$ receptors has been indicated following studies with intraduodenal application of a poorly absorbable $\mathrm{CCK}_{1}$ receptor antagonist from the benzodiazepine family, tarazepide (Solvay Pharmaceuticals, Hannover, Germany), in conscious calves (Zabielski et al. 1998b). In a rat model, Li \& Owyang (1993, 1994) showed that exogenous CCK8 infused intravenously at large doses may stimulate pancreas protein secretion directly, while low concentrations may stimulate it via vagal afferent (capsaicin-sensitive) pathways. CCK receptors, predominantly of the $\mathrm{CCK}_{1}$ type, located on the peripheral vagal afferent fibres, were suggested to be a target site for this mechanism. Gastroduodenal but not jejunal administration of capsaicin abolished the response to low doses of $\mathrm{CCK}$, confirming that the mechanism might originate in the gastroduodenal area. Thus, currently there is strong evidence for neuronal rather than endocrine action of CCK on pancreatic secretion (Owyang, 1996; Deng \& Whitcomb, 1998). The evidence for such neuronal action of CCK on the pancreas also derives from earlier studies in dogs in which atropine was found to inhibit the pancreatic secretion induced by endogenous stimulants of CCK such as leucine or tryptophan (Konturek et al. 1972), but also by lower, more physiological doses of CCK. Zabielski et al. (1995) found in conscious suckling calves that luminal administration of CCK8 resulted in the stimulation of pancreatic juice flow, and bicarbonate and protein output in a doserelated manner. The protein-secretory increments for equimolar intravenous infusions were, however, greater than for intraduodenal infusions. The effect of luminal CCK8 was delayed by several minutes in comparison with intravenous $\mathrm{CCK} 8$, which may be related to the time needed for CCK8 to permeate to the mucosal receptors, but in contrast to the latter it was atropine sensitive, indicating involvement of a cholinergic mechanism. Application of tarazepide helped to clarify the mucosal CCK-related mechanism. It was shown that an intraduodenal bolus administration of tarazepide led to immediate reduction of pancreatic secretion well before any tarazepide was detected in the portal or peripheral blood. The reduction of pancreatic secretion was observed for several hours (Zabielski et al. 1998b). Pharmacological blockage of mucosal $\mathrm{CCK}_{1}$ receptors with tarazepide alone, as well as in combination with atropine, totally abolished the pancreatic response to intraduodenal CCK8. 


\section{Cholecystokinin-gastrin family peptides and diseases: some examples}

Some GI peptides, including peptides of the CCK-gastrin family and their receptors, appear to be involved in the growth of neoplasms of the GI tract, and more particularly in the tumorigenesis of the stomach, colon and pancreas as it was described about 15 years ago (Silen \& Gardner, 1993) and then reviewed more recently (Rozengurt \& Walsh, 2001; Jensen, 2002; Morisset et al. 2004; Schally et al. 2004). In this section, the objectives are to describe some biological responses occurring upon binding of CCK and gastrin to their specific receptor subtypes in different GI organs under pathological conditions (Table 2).

\section{Gastrin and cholecystokinin effects through cholecystokinin 1 receptor occupation}

Effects on the stomach. Kawano et al. (1992) reported that OLETF rats were spontaneous mutants with little or no expression of the $\mathrm{CCK}_{1}$ receptor gene (Takiguchi et al. 1997). In these $\mathrm{CCK}_{1}$ receptor-deficient rats, it was shown that thyroxine-releasing hormone which increases vagal efferent activity, indomethacin which decreases mucosal PG levels, a protective molecule for the stomach, hydrochloric acid and ethanol which increase the severity of gastric mucosal damage, increased the severity of gastric mucosal lesions when compared with control rats. Indeed, it has been demonstrated that CCK has an anti-ulcer action on the gastric mucosa through its action via the $\mathrm{CCK}_{1}$ receptor in rats (Ohumura et al. 1996).

During chronic $H$. pylori infection, pro-inflammatory cytokines are released that can affect ECL cells, thus impairing the secretory function and viability which can predispose to hypochlorhydria and gastric carcinogenesis. Gastrin binds to specific $\mathrm{CCK}_{2}$ receptors on ECL cells and activation of these receptors causes a variety of transcriptional activities which can result in diseases such as enterochromaffin-like cells carcinoids (Prinz et al. 2003; Havu, 1986).

Effects on the exocrine and endocrine pancreas. In $\mathrm{CCK}_{1}$ receptor-deficient rats, the in vivo release of pancreatic protein in response to exogenous CCK8 and endogenous CCK-release by pancreatic juice diversion were significantly impaired (Funakoshi et al. 1994); a lack of response to CCK was also observed using freshly isolated acini from these OLETF rats (Funakoshi et al. 1994).

According to Lacourse et al. (1999), the concentration of $\mathrm{CCK}_{1}$ receptor mRNA remained normal in CCK-deficient mice, suggesting that agonist binding does not regulate receptor gene expression. Moreover, in these CCK-deficient mice, growth of their pancreas and their enzymes' adaptation to different diets remained also comparable with control values. It thus seems that other regulatory pathways took over to compensate for the CCK deficiency. These data obtained from CCK-deficient mice agree in some way with those obtained in rats without expression of the $\mathrm{CCK}_{1}$ receptor (Miyasaka et al. 1999). Indeed, in the OLETF rats, the pancreatic wet weight increases were significantly lower than in normal Long-Evans Tokushima

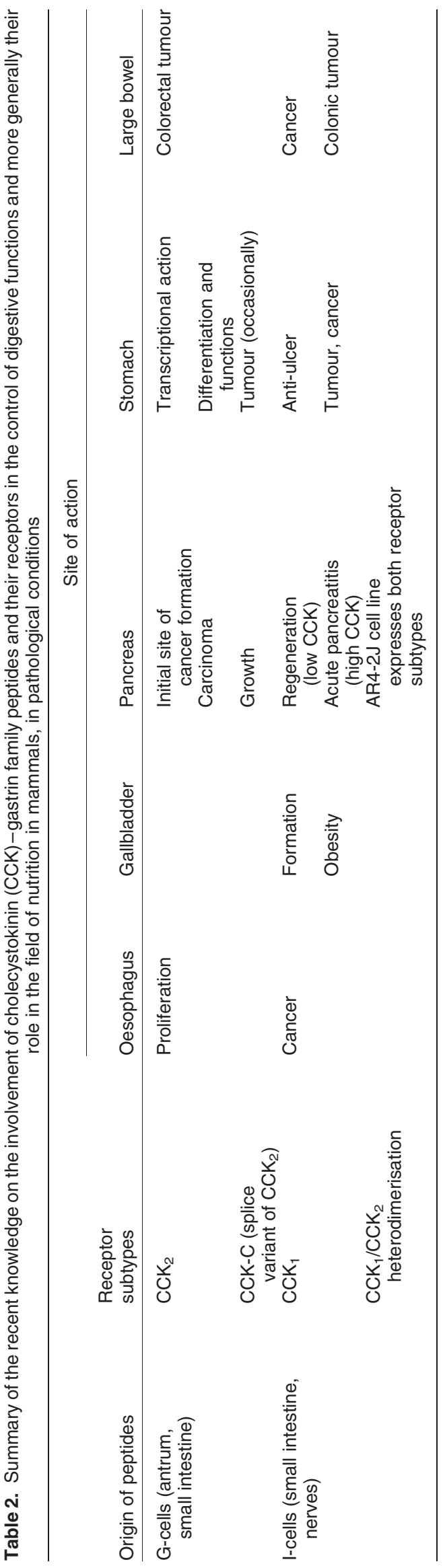


rats at all ages examined but total DNA contents in the whole pancreas and protein concentrations were comparable in both strains. These studies point to the fact that the $\mathrm{CCK}_{1}$ receptor might not be an absolute requirement for normal pancreas growth at least in rodents. Although the pancreatic gland develops normally in $\mathrm{CCK}_{1}$ receptor-deficient rats, its regeneration is significantly delayed after $30 \%$ pancreatectomy, suggesting its importance for pancreatic regeneration (Miyasaka et al. 1997b).

The absence of $\mathrm{CCK}_{1}$ receptors also impaired functions of the endocrine pancreas; although the pancreatic insulin contents were not affected in $\mathrm{CCK}_{1}$ receptor-deficient rats, its release in response to $\mathrm{CCK} 8$ remained at basal level; similarly, CCK8 had no effect on glucagon secretion while it increased the hormone release in normal pancreas. In response to a meal, plasma insulin was reduced and associated with transcient hyperglycaemia in $\mathrm{CCK}_{1}$ receptor-deficient rats. These data clearly demonstrate the importance of the $\mathrm{CCK}_{1}$ receptor in the control of insulin and glucagon secretion along with glycaemia (Funakoshi et al. 1996) and they agree with the recent co-localisation of the $\mathrm{CCK}_{1}$ receptor with insulin and glucagon by immunofluorescence (Morisset et al. 2003). In obese Zucker rats, their pancreatic protein secretion in response to increasing doses of CCK8 was significantly reduced at all doses tested; this impaired release was also associated with significant decreases in the $\mathrm{CCK}_{1}$ receptor high and low affinity sites with no modification in their respective affinity (Praissman \& Izzo, 1986).

Stimulation of the rat pancreatic gland by a supraphysiological dose of caerulein, a CCK analogue, leads to acute pancreatitis with destruction of the pancreas architecture and a loss of tissue. Regeneration of the pancreas was then observed following caerulein treatment at a physiological dose (Jurkowska et al. 1992a) during which $\mathrm{CCK}_{1}$ receptor mRNA were tremendously increased (Morisset \& Calvo, 1998). The regeneration process involved the $\mathrm{CCK}_{1}$ receptors because it was prevented by a concomitant treatment with the $\mathrm{CCK}_{1}$ receptor antagonist, L-364,718 (Jurkowska et al. 1992b).

Effects on the gallbladder. A deletion of a 262 bp coding region of the human gallbladder $\mathrm{CCK}_{1}$ receptor led to obesity and cholesterol gallstone disease in a patient with this mutation. After sequencing, it was found that the majority of the mRNA produced from this gene was abnormally processed, resulting in the deletion of the third exon; this mRNA encoded an inactive receptor unable to bind agonists. Although not yet proven in substantial number of patients, it is tempting to associate this peculiar mutation with gallstone formation and obesity (Miller et al. 1995).

\section{Gastrin and cholecystokinin effects through cholecystokinin 2 receptor occupation}

Proliferation of the oesophagus. Over the last two decades, there has been an enormous increase in the incidence of Barrett's metaplasia and oesophageal adenocarcinoma. The reasons behind this phenomenon remain poorly understood and once metaplasia is ongoing, it is highly proliferative. Since gastrin plays an important role in the regulation of GI organ proliferation and differentiation, it became important to evaluate its involvement in the regulation of Barrett's metaplasia. In a recent study (Haigh et al. 2003), $\mathrm{CCK}_{2}$ receptors were detected by RT-PCR in $30 \%$ of normal patients, in $80 \%$ of patients with oesophagitis, in $100 \%$ of patients with Barrett's metaplasia and in $70 \%$ of patients with oesophageal adenocarcinomas. In the Barrett's group, all patients expressed twice the amount of $\mathrm{CCK}_{2}$ receptors than the controls. In Barrett's mucosal biopsies, gastrin significantly increased DNA synthesis, an effect blocked by the $\mathrm{CCK}_{2}$ receptor antagonist L-740,093. The overexpression of the $\mathrm{CCK}_{2}$ receptor in Barrett's metaplasia may have implications for the management of patients in whom gastrin is elevated by acid-suppression therapy.

Alterations in the stomach. One way to investigate the effects of gastrin on the stomach components and functions is to remove the major site of gastrin production, the gastric antrum. However, contradictory data came out regarding this surgical procedure on the stomach physiology (Martin et al. 1970; Lehy et al. 1973). With the event of molecular biology and gene manipulation, receptor-deficient mice were produced and so were mice without $\mathrm{CCK}_{2}$ receptors. In such animals, a marked increase in basal gastric $\mathrm{pH}$ was observed along with major increases in plasma gastrin. In the stomach of these deficient animals, parietal and ECL cells were decreased, explaining the reduction in acid output. In the antrum, the gastrin cell population was increased with a reduction in that of the somatostatin cells, consistent with increased plasma gastrin. These data stress the importance of the $\mathrm{CCK}_{2}$ receptors to maintain normal cellular composition, distribution and functions of the gastric gland (Langhans et al. 1997). In similar $\mathrm{CCK}_{2}$ receptor-deficient mice, the following alterations were also observed: thinning of the oxyntic mucosa; reduction in parietal cell number; absence of normal ECL cells with undetectable histidine decarboxylase activity responsible for histamine synthesis. These major changes in the stomach structure and functions plead for a strategic role of the $\mathrm{CCK}_{2}$ receptors in differentiation and functions of the stomach (Chen et al. 2002).

Alterations in the pancreas: transfection of the cholecystokinin 2 receptors in normal mice pancreas. With transfection of the human $\mathrm{CCK}_{2}$ receptor in mouse pancreatic acinar cells, a location where it does not belong normally (Morisset et al. 2003), the pancreas of these mice grow significantly bigger at $50 \mathrm{~d}$ of life when compared with controls. However, when these mice were crossed with gastrin-mice expressing gastrin in their pancreatic $\beta$-cells to obtain continuous gastrin release and thus stimulation of the $\mathrm{CCK}_{2}$ receptors, some of these animals (three out of twenty homozygous) developed malignant transformations through an acinar-ductal carcinoma sequence (Clerc et al. 2002). When oedematous pancreatitis is induced in rats by supramaximal doses of caerulein, the pancreas of these animals begins to express the $\mathrm{CCK}_{2}$ receptor early during the destruction process of the gland. However, if a treatment to induce pancreas regeneration by low doses of caerulein is not begun, the $\mathrm{CCK}_{2}$ receptor mRNA expression vanished 
while it is sustained during $4 \mathrm{~d}$ with repeated injection of caerulein (Morisset \& Calvo, 1998). Expression of $\mathrm{CCK}_{2}$ in the murine pancreas was also shown to modulate acinar cell adhesion and cell differentiation (loss of cell polarity, defective secretion) in vivo. This result suggests an implication in initial sites of cancer formation in conjunction with chemical carcinogens (Bierkamp et al. 2004).

Alterations in the pancreas: stable transfection of cholecystokinin receptors in human pancreatic cell lines.

Transfection of equal amounts of $\mathrm{CCK}_{1}$ and $\mathrm{CCK}_{2}$ receptors in pancreatic Panc and Mia Paca cancerous cells led to a sustained inhibition of their anchorage-independent and also anchorage-dependent growth. In these cells, DNA synthesis was also inhibited in a CCK8-dependent concentration (Detjen et al. 1997). These inhibitions observed in the presence of CCK8 in these cancer cells differ from a stimulation of rat pancreatic acinar cell growth by CCK in vitro (Logsdon, 1986). These opposite responses are not yet quite understood but may indicate that human cancerous cells of ductal origin behave differently from normal acinar cells isolated from rat pancreas.

Alterations in the pancreas: expression of cholecystokinin receptors in human cancer cells. In six different pancreatic cell lines, binding of $\left[\mathrm{H}^{3}\right] \mathrm{L}-365,260$, a potent $\mathrm{CCK}_{2}$ receptor antagonist, was specific in all cells with variable concentrations of receptor per cell; $\mathrm{CCK}_{1}$ receptors could not be identified in any cell line (Palmer-Smith et al. 1994). GI tumour cell lines from gastric and colorectal origin, all express the $\mathrm{CCK}_{2}$ receptor with some of them expressing a truncated receptor. These $\mathrm{CCK}_{2}$ truncated receptor cells were always coupled with co-expression of the gastrin gene, implying that a gastrin- $-\mathrm{CCK}_{2}$ autocrine loop may operate in these cells (McWilliams et al. 1998).

Alterations in the pancreas: expression of cholecystokinin receptors in human tumours. In rat pancreatic carcinoma obtained from implanted DSL-6 cells (azaserine-induced pancreatic carcinoma), $\mathrm{CCK}_{1}$ receptors already present on these cells were overexpressed while novel expression of the $\mathrm{CCK}_{2}$ receptors was observed (Zhou et al. 1992). From CCK receptor evaluation by in vitro receptor autoradiography, $\mathrm{CCK}_{2}$ receptors were found occasionally in gastroenteropancreatic tumours while the $\mathrm{CCK}_{1}$ subtype was often present (Reubi et al. 1997). The expression of both CCK receptor subtypes in human GI cancers remains poorly documented and is still of a controversial nature. For example, by RT-PCR, $\mathrm{CCK}_{1}$ receptor mRNA was detected in oesophageal cancers, in gastric cancers and in colon cancers; on the contrary, $\mathrm{CCK}_{2}$ receptor mRNA was absent from oesophageal cancers, detected in gastric cancer and in few colon adenocarcinomas (Clerc et al. 1997). Their absence from oesophageal cancers disagrees with another study in which oesophageal adenocarcinomas expressed the $\mathrm{CCK}_{2}$ receptors in $70 \%$ of the patients, using the same technique (Haigh et al. 2003). From a study using autoradiography as a means of receptor detection, it was shown that ductal pancreatic carcinomas rarely expressed both subtypes of CCK receptor; tumours of neuroendocrine differentiation sometimes expressed the $\mathrm{CCK}_{2}$ receptor at the mRNA and protein level (Reubi et al. 2003). Contrary to normal human pancreas which expressed only traces of poorly processed progastrin, most pancreatic carcinomas and resection margin samples synthesised amidated gastrin. $\mathrm{CCK}_{2}$ receptor mRNA was present in all pancreatic carcinomas, resection margins, and normal pancreatic tissue. Most tumours possess the $\mathrm{CCK}_{1}$ receptor but the $\alpha$ admidated and O-sulfated CCK peptides were absent from carcinoma and normal pancreatic tissue. These data support the hypothesis for a local gastrin regulatory mechanism in growth of pancreatic carcinoma (Goetze et al. 2000). Moreover, angiogenesis is the production of new blood vessels from pre-existing ones. This process is necessary for the growth and metastasis of solid tumours. Gastrin induces marked pro-angiogenic effects both in vitro (in human endothelial cells) and in vivo (in human experimental glioma). CCK8 had marginal effects only. Moreover, a $\mathrm{CCK}_{2}$ receptor antagonist $(\mathrm{L} 365,260)$ significantly antagonised the in vivo G17-mediated pro-angiogenic effects in gliomas, whereas a $\mathrm{CCK}_{1}$ receptor antagonist $(\mathrm{L} 364,718)$ did not (Lefranc et al. 2004).

\section{Other actions in pathological conditions}

Cholecystokinin cancer receptor occupation. It is likely that gastrin and CCK influence the growth of the malignant cells of the pancreas and phenotypic transformation (Silen $\&$ Gardner, 1993). Many data reveal the presence of a unique CCK receptor in human pancreatic cancer that functions in growth and is not present in the normal human pancreas. It was well characterised and the term CCK-C receptor or 'cancer' receptor, has been proposed to signify the relationship of this receptor to neoplasia (Smith et al. 2002). This CCK-C receptor is completely different from another type of CCKc receptor (see p. 264). It is functional and plays a crucial role in the growth of human cancer. It is a splicing variant of the $\mathrm{CCK}_{2}$ receptor which differs from the $\mathrm{CCK}_{2}$ receptor by the presence of intron 4 (Smith et al. 2004). It is also expressed in colonic tumours, hepatic metastases and an I-cell line (sk-Co15) (Biagini et al. 1997). Moreover, $\mathrm{CCK}_{2}$ receptors which are not present in normal rat pancreas constituted about $34 \%$ of the total high-affinity CCK receptors in tumours. It was suggested that the expression of $\mathrm{CCK}_{2}$ receptors might be induced by gene mutation or amplification during carcinogenesis and may promote tumour growth (Zhou et al. 1992). Tumours of the central and peripheral nervous system exhibited both $\mathrm{CCK}_{2}$ and/or CCK-C receptors (Lefranc et al. 2003).

Heterodimerisation of cholecystokinin 1 and cholecystokinin 2 receptors. Dimerisation of several GPCR have recently been described, but little is known about their clinical and functional relevance. $\mathrm{CCK}_{1}$ and $\mathrm{CCK}_{2}$ receptors have been found to co-localise in selected areas of the brain where opioids have effects, and both of these receptors have been described to be expressed on AR42J cells. $\mathrm{CCK}_{1}$ and $\mathrm{CCK}_{2}$ receptor heterodimers bind natural agonists normally, but they exhibit unusual functional and regulatory characteristics. Such complexes demonstrated enhanced agonist-stimulated cellular signalling and delayed 
agonist-induced receptor internalisation. As a likely consequence, agonist-stimulated cell growth was markedly enhanced in cells simultaneously expressing both of these receptors. These results provide the first evidence of interaction between subtypes of $\mathrm{CCK}_{1}$ and $\mathrm{CCK}_{2}$ receptors, along with unique and potentially quite important functional consequences. The physiological and pharmacological activities of CCK and gastrin that have been observed are complex and have been difficult to understand based on the existence of only $\mathrm{CCK}_{1}$ and $\mathrm{CCK}_{2}$ receptor subtypes. Examples of this include the observations that, neither $\mathrm{CCK}_{1}$ nor $\mathrm{CCK}_{2}$ receptor antagonists are able to antagonise the antinociceptive action of CCK in the mouse, and the spectrum of antagonist affinities for CCK receptors on the AR42J rat pancreatic tumour cell line is not consistent with either subtype $\mathrm{CCK}_{1}$ or subtype $\mathrm{CCK}_{2}$ receptors (Cheng et al. 2003).

\section{Applications - future challenges}

Over the last 20 years, considerable progress has been made in understanding the physiological factors that regulate CCK and gastrin secretion. These advances have been made possible by the development of specific assays for measuring $\mathrm{CCK}$ and gastrin in blood and tissues and the appropriate use of animal models for examining pharmacological agents and nutrients that affect peptide release. These studies have laid out the groundwork for more extensive investigation in animal and human physiology of nutrition and diseases. Thus, the suggestion that gastrin and CCK might also promote the development of cancers of the GIT has been controversial, but an increasing body of evidence now supports the view that the amidated and nonamidated forms of gastrins act as growth factors via different receptors in different regions of the gut.

\section{Gastrin, cholecystokinin and performances}

The biological properties of gastrin and CCK as well as their intermediate forms or the molecules involved in their mechanism of action could be used to increase the development (growth and maturation) of the GIT and the digestive performances in animal and human nutrition by using directly these peptides or by the way of increasing their endogenous production and release. For example, in the pig, an enhanced pancreatic function might help to ameliorate the problems that may appear in modern pig production which are associated with weaning. Indeed a red kidney bean lectin treatment was shown to result in an increased capacity of pancreatic enzyme secretion in the suckling piglets due to an increase in CCK secretion (Evilevitch et al. 2005). In calves fed milk replacer containing soya proteins, sodium butyrate, used as an additive in the diet, improved the GIT maturation and increased pancreatic enzyme secretion simultaneously with an elevation of blood levels of gastrin and mainly CCK (Guilloteau et al. 2004). Moreover, it was shown that the diet component digestibility depends on pancreatic enzyme quantity present in the proximal duodenum (Guilloteau et al. 1999; Guilloteau \& Zabielski, 2005b).
In human nutrition, incorporation of fibres in the diet is often suggested. Recently, in hypercholesterolaemic men and women, it was shown that solubilised cellulose fibre (free of a multitude of components linked to the plant cell wall, for example, phytic acid, plant sterols, saponins) decreased peak postprandial glucose concentrations after a liquid mixed meal via a decrease in peak postprandial blood CCK concentrations (Geleva et al. 2003). These findings may suggest that plasma CCK could act on the absorption rate of nutrients and consequently could be implicated in the maintenance of good health. In man, the concept of 'fast' and 'slow' proteins was introduced by Boirie et al. (1997) to describe the differences in digestion and absorption of whey and casein, and, as a remark, more than 20 years before, by Guilloteau et al. (1975) in calves fed milk replacer. Using this concept, Hall et al. (2003) have shown that a preload drink of whey protein is associated with a higher postprandial circulating level of amino acids and CCK compared with an isoenergetic casein preload. This can help in the treatment of obesity and weight management as well as less satiating foods containing 'slow' proteins that might be useful in clinical nutrition as sip feeds for elderly or sick patients where increased food intake is desired. In another way, total parenteral nutrition does not stimulate pancreatic secretion and blood gastrin and CCK levels contrary to oral and/or enteral nutrition, underlining the importance of the mucosal origin of the stimuli (O'Keefe et al. 2003), even if CCK could also act via paracrine and/or neurocrine pathways.

\section{Molecular forms: roles and therapy}

Globally, the metabolic clearance rate of the CCK-gastrin family peptides is proportional to the length of the molecular forms, and the actions regarding the molecular forms depend on species as well as the origin (exogenous $v$. endogenous). Different molecular forms have specific localisations and roles (see pp. 225-256 and pp. 258260). The regulation of sulfatation alters the pattern of physiological activity of CCK by changing an exclusive $\mathrm{CCK}_{1}$ agonist into an agonist for both $\mathrm{CCK}_{1}$ and $\mathrm{CCK}_{2}$ receptors. Therefore, the physiological relevance of nonsulfated CCK58 (CCK58NS) can be evaluated by determining (1) its existence in blood, brain and peripheral nerves, (2) if there are physiological states that alter the ratio of sulfated and non-sulfated forms of CCK in these tissues and (3) if the concentrations of CCK58NS are sufficient to activate $\mathrm{CCK}_{2}$ receptor in an endocrine, paracrine or neurocrine manner (Reeve et al. 2004a). Synthetic canine CCK58 stimulated rat bile pancreatic volume whereas CCK8 caused no increase in volume (Reeve et al. 2004b). In addition, purified porcine CCK58 produced a pattern for contraction of the gallbladder different from that of CCK8 (Tatemoto et al. 1984). By contrast, porcine CCK33 and CCK8 had similar potencies for stimulation of amylase release from purified acinar cells (Liddle et al. 1986). The similar activity of CCK8 and CCK33 and the different activity of CCK58 suggest that the region outside the $\mathrm{COOH}$ terminus of rat CCK58 influences expression of $\mathrm{CCK}$ biological activity and/or binding and activation of the $\mathrm{CCK}_{1}$ receptor (Reeve et al. 2003b). In the case of blood 
perfusion of the regulatory substance, the administered molecular form could determine the effects evoked in the pancreas. Thus, during continuous infusion of sulfated CCK8 (CCK8S), the decreased apoptosis could explain the increased pancreatic weight. By contrast, upon intermittent injections of CCK8S, an increased apoptosis could explain the lack of pancreatic weight gain despite the stimulation of cell proliferation. Injections of CCK8S only transiently decreased the tissue levels of its receptor (Ohlsson et al. 2001). These findings also suggest that the method of administration of the regulatory substance could be implicated.

Concerning gastrin, the full-length precursor progastrin (human progastrin ${ }_{1-80}$ ) molecule is more potent as a growth factor for large intestinal epithelial cells, for the normal colon and in vitro, than the incompletely processed Glyextended gastrins and the completely processed peptides (G17), via high-affinity binding sites (Wang et al. 1996; Singh et al. 2003). Moreover, this stimulation is similar with progastrin $_{6-80}$, indicating that the first five residues are not required for biological activity (McQueen et al. 2002). In addition, progastrin may act as a co-carcinogen in the development of colorectal carcinoma (Singh et al. 2000). In a similar way, available data indicate that proCCK is expressed in certain neuroendocrine tumours and sarcomas whereas the secretion of CCK is impaired in coeliac disease and bulimia nervosa (Rehfeld, 2004).

Taking these results together, it seems clear that total immunoreactivity following a RIA measurement for gastrin or CCK cannot provide a reliable indicator of the identity and properties of all the active-derived peptides in different conditions. This is true for most of the prepeptides and biosynthetic intermediates which can have their own effects. Thus, the RIA generally used to determine plasma gastrin do not react with progastrin or biosynthetic intermediates such as the COOH-terminal Gly-extended gastrins (Dockray, 2004). These last products are now thought to have their own biological properties and sometimes are associated with cancers (pancreatic adenocarcinoma, colorectal carcinoma, lung cancer) and nutritional diseases (obesity, intestinal malabsorption).

Diagnosis. To have a better diagnosis as well as a better comprehension of the mechanisms involved, an evaluation of the molecular forms and of the intermediate peptides occurring during the biosynthesis is more and more relevant. Thus, non-classical RIA to determine the multiple classes of gastrin may therefore prove necessary for full analysis in the management of patients with gastrin-related disease (Varro $\&$ Ardill, 2004). Another situation in which it is necessary to have a representative diagnostic is to know the degree of pancreatic insufficiency in patients with pancreatitis or pancreatic duct obstruction. In this case, CCK is useful as a single agent for stimulating direct pancreatic enzyme secretions and measurements in the absence of commercially available secretin (Pfefferkorn et al. 2002). Simple quantitative measurement of duodenal fluid lipase may be a marker of pancreatic secretory function and this physiological observation can serve as basis for further investigation of CCK-stimulated lipase concentration as a new test in the assessment of pancreatic insufficiency
(Conwell et al. 2002). Thus, stimulation with exogenous CCK has been proven useful in diagnostic tests of gallbladder and pancreatic diseases (Rehfeld, 2004). In another way, Konturek et al. (2003a) concluded by suggesting that determination of high serum progastrin, amidated gastrins and IL-8 combined with low serum pepsinogen I may be useful biomarkers of gastric cancer (often associated with an $\mathrm{H}$. pylori infection) with acute pangastritis followed by chronic active gastritis, gastric atrophy, intestinal metaplasia and displasia. In addition to standard markers such as pepsinogen, gastrin and IL-8, reactive oxygen species were recently confirmed as biomarkers in patients with gastric inflammation (Naito et al. 2005).

Therapy. Agonist and antagonist tools could be used as therapy. For example, the generation of antibodies to gastrin that bind and thereby sequester the hormone is the basis of the antigen G17DT (Watson \& Gilliam, 2001). The immunogen raises antibodies that bind the $\mathrm{NH} 2$-terminus of G17 and G17-Gly; it is therefore uncertain whether they neutralise other active forms. G17 is a growth factor for pancreatic, stomach and colorectal cancers, and a potent stimulator of gastric acid secretion. The anti-gastrin immunogen, G17DT, consists of a large carrier protein, called diptheria toxoid (DT) and a synthetic peptide, similar to a portion of the G17 hormone, attached to the carrier protein. When administered to patients, G17DT induces an immune response producing antibodies which cross-react and neutralise the target hormone thus preventing its interaction with disease-causing or -participating cells. G17DT has recently been submitted to different phases of approval in the USA, Australia and European Union for the treatment of gastric and pancreatic cancers (Dockray, 2004). In another way, concerning the immune system, exogenous administration of neuropeptides to maintain normal immune defences represents a new field of pharmacotherapeutics against bacterial invasion (Genton \& Kudsk, 2003).

\section{Cholecystokinin-gastrin family receptors}

The CCK receptor subtypes remain the key elements to all the unanswered questions and controversial responses to CCK and gastrin related to their physiological effects. Due to recent insights elucidating the structure of the two GPCR that mediate their cellular actions, characterisation of receptor location, peptide and receptor genes, development of receptor antagonists and receptor and peptide knockout animals, especially the role of gastrin and CCK and to a lesser extent, gastrin, in normal GI physiology as well as in clinically important GI pathological states, was recently clarified, but again, remains unclear and in many cases, controversial (Jensen, 2002). Again now, it is mandatory to establish the respective cellular location of the CCK receptor subtypes in different organs and in various species for potential therapies with selective and appropriate hormones and receptor inhibitors. Such studies will help to understand physiological responses to $\mathrm{CCK}$ and gastrin and thus eliminate many controversies. $\mathrm{CCK}_{1}$ and $\mathrm{CCK}_{2}$ receptor gene-deficient animal models could be useful. In the near 
future, we will have to deal with the phenomenon of CCK receptor heterodimerisation to explain some integrated physiological responses. It also continues to be necessary to understand the mechanism of the $\mathrm{CCK}_{1}$ receptor promoter polymorphism as it is related to disease processes such as chronic pancreatitis, gallstone formation as well as psychiatric disorders (Miyasaka \& Funakoshi, 2003). Polymorphism in the $\mathrm{CCK}_{2}$ receptor can alter ligand affinity and activity as well as basal (or ligand-independent) signalling (Kopin et al. 2000; Ji et al. 2000). Thus, species differences between rat and mouse $\mathrm{CCK}_{1}$ receptors determine the divergent acinar cell response to the CCK analogue JMV-180.

Biologically active amidated gastrins act as potent cellular growth factors that are implicated in a variety of normal and abnormal biological processes including maintenance of the gastric mucosa, proliferation of ECL cells, and neoplastic transformation. The expression of the $\mathrm{CCK}_{2}$ receptor in human cancers has also been documented. Studies in transgenic mice and in cultured tumours have suggested that incompletely processed gastrins may have trophic activity independent of amidated gastrins. An important task for the future will be to identify the specific receptor(s) that mediates the biological responses induced by these gastrins and to develop cell model systems and specific antagonists for studying the intracellular signalling pathways stimulated by these novel receptors (Rozengurt \& Walsh, 2001). Thus, as for other GPCR, the cloning of $\mathrm{CCK}$-gastrin family receptor cDNA and genes has stimulated the generation of new biological models (transgenic animals, GM cells, etc) and opened new avenues for research in physiology, pathophysiology, molecular pharmacology and structure-function relationships of receptors.

A number of antagonist and agonist tools are available and could be used as therapeutic treatments (Black \& Kalindjian, 2002). Thus, on one hand, a $\mathrm{CCK}_{1}$ antagonist might have therapeutic potential for the treatment of pancreatic disorders as prokinetics for the treatment of gastro-oesophageal reflux disease, bowel disorders and gastroparesis. On the other hand, a $\mathrm{CCK}_{2}$ antagonist might have application for the treatment of gastric acid secretion and anxiety disorders (Herranz, 2003). As a first example, since $\mathrm{CCK}$ is involved in sensory and motor responses to distension in the GIT (by the way of the $\mathrm{CCK}_{1}$ receptor), it may contribute to the symptoms of constipation, bloating and abdominal pain that are often characteristic of functional GI disorders in general and in irritable bowel syndrome, in particular; $\mathrm{CCK}_{1}$ receptor antagonists are therefore currently under development for the treatment of constipation-predominant IBS (Varga et al. 2004). As a second example, an impairment of pancreatic exocrine function in acute pancreatitis, together with a transient disturbance of bile flow into the duodenum by stones or oedema of the pancreas, may cause an increase in plasma CCK release. The increased CCK may further aggravate pancreatitis and worsen the prognosis of acute pancreatitis by stimulating the injured pancreas, resulting in the vicious cycle via endogenous CCK release. The $\mathrm{CCK}_{1}$ receptor antagonist may have exhibited its therapeutic usefulness in acute pancreatitis by breaking the vicious cycle (Otsuki,
2000). In a similar way, a variety of potential therapeutic approaches based on the biology of gastrin and its receptors are currently under exploration, including receptor antagonists and the targeted delivery of imaging and cytotoxic agents (Dockray, 2004), but the efficacy of theses therapies needs to be determined.

New techniques to be utilised for detection or therapy of disease implicating cholecystokinin-gastrin family peptides

Several types of diseases are linked to the peptides from the $\mathrm{CCK}$-gastrin family in relation to their receptor subtypes. The first group contains biliary dyskinesia which includes both chronic acalculous cholecystisis and sphincter of Oddi spasm which are well detected by techniques using CCK and/or gastrin assays. Measurement of gallbladder ejection (GBEF) with an intravenous infusion of exogenous CCK8 can be cited as an example of a test method (Krishnamurthy \& Krishnamurthy, 1997). Patients with diabetes have lower plasma levels of CCK which may explain their relatively hypotonic gallbladder and reduced gastric motility (Bucceri et al. 2002). The abilility to potentially modify different populations of enteroendocrine cells may become an important therapeutic strategy for treating and/or preventing a variety of common human diseases such as diabetes and obesity (Schonhoff et al. 2004). New therapy in some nutritional diseases appears in using regulatory peptides. As an example, Brand et al. (2002) have demonstrated that systemic administration of gastrin or epidermal growth factor can stimulate islet neogenesis in adult diabetic animals resulting in an increased pancreatic secretion and improvement of blood glucose level. Thus, gastrin or epidermal growth factor treatement is potentially an attractive alternative to islet transplantation achieving $\beta$ islet cell replacement without invasive surgery or immunosuppression needed to prevent transplant rejection.

Another group, the pathogenesis of the cancers, causes more drastic consequences in the human population as recently reported by global statistics (Burch et al. 2000; Parkin et al. 2005). Overall, each year, there were 10.9 millions new cases, 6.7 million deaths and 24.6 million individuals alive with cancer (within 3 years of diagnosis until 2002). Among the total cases, GIT cancers (i.e. strictly oesophageal, stomach, pancreas and colorectal cancers) represent almost $25 \%$. Colorectal cancer is the most abundant $(9.4 \%)$, but the relatively good prognosis means that mortality is about half that incidence (about 0.53 million deaths in 2002), while prevalence is second only to that of breast cancer wordwide ( $23 \%$ of total cancers). Until recently, stomach cancer was the second most common cancer, but in 2002 it represented only $8.6 \%$ of the new cancer cases and is often linked to $H$. pylori infection. Oesophageal cancer is the eighth most common cancer wordwide ( $4.2 \%$ of the total) and sixth most common cause of death from cancer (cancer of the oesophagus has a very poor survival). Pancreatic cancer is responsible for 0.23 million deaths annually ( $2.2 \%$ of total cancers) and have a relative higher rank for incidence (thirteenth) because of the very poor prognosis (the mortality:incidence ratio is $98 \%$ ). Early diagnosis and screening for non-endocrine pancreatic cancer is difficult although the technology for detecting 
these small tumours is available (Comaru-Schally \& Schally, 1990; Watson \& Gilliam, 2001).

The delay of detection is mostly due to the fact that early symptoms are usually vague, non-specific and very often neglected by the patients and missed by the physicians. Although surgical resection has been shown to improve survival, the majority of patients have disease that has spread beyond the pancreas by the time of diagnosis. Unfortunately, treatment with chemotherapeutic agents has not significantly impacted the natural history of this cancer, with fluorouracil (Schnall \& Macdonald, 1991) and gemcitabine (Casper et al. 1994) offering 4.4 and 5.6 months survival respectively. Thus, conventional chemotherapy has not produced dramatic improvements in response rates or patient survival. Possible new approaches to treat this malignancy could be based on inhibition of gastrin and CCK or their receptors by administration of hormonal peptide analogues as well as on monoclonal antibodies against oncogene receptors; this philosophy could be applied in the case of similar diseases caused by other gut regulatory peptides and/or their own receptors (Schally et al. 2004). Because of the poor response of pancreatic cancer to standard chemotherapy and radiation therapy, the investigators have studied this malignancy to determine the mechanisms that are responsible of its growth regulation. Since an additional sixty-nine amino acids in the third intracellular loop of the CCK-C receptor is associated with accelerated growth, it could be speculated that by blocking the translation or function of this portion of the receptor, one could establish normal growth. Additionally, selective gene therapy targeted at the unspliced segment of the CCK-C receptor could possibly restore cancerous cells to normal growth. Thus, Smith et al. (2002) have shown that an antibody produced against this receptor inhibited pancreatic cancer cell growth in culture; this specific antibody could be used to detect pancreatic cancer in the early stages. Moreover, elimination of this CCK-C receptor through antisense technology arrests growth in culture and inhibits growth of established tumours in mice (Smith et al. 2004). This form of therapy may be useful clinically for patients with established pancreatic cancer.

\section{Conclusion}

In conclusion, after respiration (and oxygenation), nutrition can be considered as the second vital function in mammals since its aim is to transform the components of the diet into nutrients directly absorbable across the wall of the GIT and then to bring the nutrients towards the numerous body cells. This function is under the dependence of an immunohormono-nervous regulation by the way of a multitude of regulatory substances; among them, CCK-gastrin family peptides (and their receptors) play a key role in physiological conditions. These peptides are also involved in several pathological states. Intestinal epithelial cell proliferation is essential for the maintenance of the multilayered defence, digestion and absorption of the GIT. However, excess proliferation is also associated with increased risk of cancer. Thus, even if considerable progresses were recently obtained in this field, a better knowledge of the mechanisms involved could be useful to increase the efficiency of the nutritional function as well as to treat the abnormalities in pathological conditions.

\section{Acknowledgements}

Thanks are due to A. Barbeau and J. Chevalier (INRASENAH, St Gilles, France) for their help in bibliographical research and presentation of illustration, respectively, as well as to A. Sahar for English revision.

\section{References}

Aly A, Shulkes A \& Baldwin GS (2004) Gastrins, cholecystokinins and gastrointestinal cancer. Biochimica et Biophysica Acta 1704, $1-10$.

Attoub S, Levasseur S, Buyse M, Goïot H, Laigneau JP, Moizo L, Hervatin F, Le Marchand-Brustel Y, Lewin JM \& Bado A (1999) Physiological role of cholecystokinin B/gastrin receptor in leptin secretion. Endocrinology 140, 4406-4410.

Avila CG, Harding R, Young IR \& Robinson PM (1989) The role of gastrin in the development of the gastrointestinal tract in fetal sheep. Quarterly Journal of Experimental Physiology 74, $169-180$

Bado A, Levasseur S, Attoub S, et al. (1998) The stomach is a source of leptin. Nature 394, 790-793.

Baintner K (2002) Vacuolation in the young. In Biology of the Intestine in Growing Animals, pp. 55-110 [R Zabielski, PC Gregory and B Weström, editors]. Amsterdam: Elsevier.

Bakke I, Qvigstad G, Sandvik AK \& Waldum HL (2001) The CCK-2 receptor is located on the ECL cell, but not on the parietal cell. Scandinavian Journal of Gastroenterology 36, $1128-1133$.

Baldwin GS (1995) The role of gastrin and cholecystokinin in normal and neoplasmic gastrointestinal growth. Journal of Gastroenterology and Hepatology 10, 215-232.

Baldwin GS, Chandler R, Scanlon DB \& Weinstock J (1986) Identification of a gastrin binding protein in porcine gastric mucosal membranes by covalent cross-linking with iodinated gastrin. Journal of Biological Chemistry 261, 12252-12257.

Beales I, Blaser MJ, Srinivasan S, Calam J, Perez-Perez GI, Yamada T, Scheiman J, Post L \& Del Valle J (1997) Effect of Helicobacter pylori products and recombinant cytokines on gastrin release from cultured canine $\mathrm{G}$ cells. Gastroenterology 113, 465-471.

Berthoud HR, Kressel M, Raybould HE \& Neuhuber WL (1995) Vagal sensors in the rat duodenal mucosa: distribution and structure as revealed by in vivo DiI-tracing. Anatomy and Embryology 191, 203-212.

Berthoud HR \& Patterson LM (1996) Anatomical relationship between vagal afferent fibers and CCK-immunoreactive enteroendocrine cells in the rat small intestinal mucosa. Acta Anatomica (Basle) 156, 123-131.

Besedovsky HO \& Rey AD (1996) Immune-neuro-endocrine interactions: facts and hypotheses. Endocrine Reviews 17, 64-102.

Biagini P, Monges G, Vuaroqueaux V, Parriaux D, Cantaloube JF \& De Micco P (1997) The human gastrin/cholecystokinin receptors: type $\mathrm{B}$ and type $\mathrm{C}$ expression in colonic tumors and cell lines. Life Sciences 61, 1009-1018.

Bierkamp C, Bonhoure S, Mathieu A, Clerc P, Fourmy D, Pradayrol L, Seva C \& Dufresne M (2004) Expression of cholecystokinin-2/gastrin receptor in the murine pancreas modulates cell adhesion and cell differentiation in vivo. American Journal of Pathology 16, 2135-2145. 
Biernat M, Zabielski R, Sysa P, Sosak-Świderska B, Le HuerouLuron I \& Guilloteau P (1999) Small intestinal and pancreatic microstructures are modified by an intraduodenal CCK-A receptor antagonist administration in neonatal calves. Regulatory Pepides $\mathbf{8 5}, 77-85$.

Björkqvist M, Dornonville de la Cour C, Zhao CM, GagnemoPersson R, Hakanson R \& Norlen P (2002) Role of gastrin in the development of gastric mucosa, ECL cells and A-like cells in newborn and young rats. Regulatory Peptides 108, 73-82.

Black JW \& Kalindjian SB (2002) Gastrin agonists and antagonists. Pharmacology and Toxicology 91, 275-281.

Blackshaw LA \& Grundy D (1990) Effects of cholecystokinin CCK8 on two classes of gastroduodenal vagal afferent fiber. Journal of the Autonomic Nervous System 31, 191-202.

Boirie Y, Dangin M, Gachon P, Vasson MP, Maubois JL \& Beaufrere B (1997) Slow and fast dietary proteins differently modulate postprandial protein accretion. Proceedings of the National Academy of Science USA 94, 14930-14935.

Bourassa J, Lainé J, Kruse ML, Gagnon MC, Calvo E \& Morisset J (1999) Ontogeny and species differences in the pancreatic expression and localization of the $\mathrm{CCK}_{\mathrm{A}}$ receptors. Biochemical and Biophysical Research Communications 260, 820-828.

Brand SJ \& Fuller PD (1988) Differential gastrin gene expression in rat gastrointestinal tract and pancreas during neonatal development. Journal of Biological Chemistry 263, 5341-5347.

Brand SJ, Tagerud S, Lambert P, Magil SG, Tatarkiewicz K, Doiron K \& Yan Y (2002) Pharmacological treatment of chronic diabetes by stimulating pancreatic $\beta$-cell regeneration with systemic co-administration of EGF and gastrin. Pharmacology and Toxicology 91, 414-420.

Brants F \& Morisset J (1976) Trophic effect of cholecystokininpancreozymin on pancreatic acinar cells from rats of different ages. Proceedings of the Society for Experimental Biology and Medicine 153, 523-527.

Brodish RJ, Kuvshinoff BW, Fink AS, McFadden DW, Turkelson J \& Solomon TE (1994a) Potentiation of acid-induced pancreatic bicarbonate output by amino acid is mediated by neural elements, but not by circulating cholecystokinin. Annals of the New York Academy of Science 713, 391-392.

Brodish RJ, Kuvshinoff BW, Fink AS, Turkelson J, McFadden DW \& Solomon TE (1994b) Intraduodenal acid augments oleic acid (C18)-induced cholecystokinin release. Annals of the New York Academy of Science 713, 388-390.

Brzozowski T, Konturek PC, Konturek SJ, Pajdo R, Duda A, Pierzchalski P, Bielanski W \& Hahn EG (1999) Leptin in gastroprotection induced by cholecystokinin or by a meal. Role of vagal and sensory nerves and nitric oxide. European Journal of Pharmacology 374, 363-376.

Bucceri AM, Calogero AE \& Brogna A (2002) Gallbladder and gastric emptying: relationship to cholecystokininemia in diabetics. European Journal of Internal Medicine 13, 123-128.

Buffa R, Solcia E \& Go VL (1976) Immunohistochemical identification of the cholecystokinin cell in the intestinal mucosa. Gastroenterology 70, 528-532.

Bunnett NW, Debas HT, Turner AJ, Kobayashi R \& Walsh JH (1988) Metabolism of gastrin and cholecystokinin by endopeptidase 24.11 from the pig stomach. American Journal of Physiology 255, G676-G684.

Burch PA, Block M, Schroeder G, et al. (2000) Phase III evaluation of octreotide versus chemotherapy with 5-fluorouracil or 5fluorouracil plus leucovorin in advanced exocrine pancreatic cancer: a North Central Cancer Treatment Group study. Clinical Cancer Research 6, 3486-3492.

Casper ES, Green MR, Kelsen DP, Heelan RT, Brown TD, Flombaum CD, Trochanowski B \& Tarassoff PG (1994) Phase II trial of gemcitabine $\left(2,2^{\prime}\right.$-difluorodeoxycytidine $)$ in patients with adenocarcinoma of the pancreas. Investigation in New Drugs $\mathbf{1 2}$ 29-34.

Chang RSL \& Lotti VJ (1986) Biochemical and pharmacological characterization of an extremely potent and selective nonpeptide cholecystokinin antagonist. Proceedings of the National Academy of Sciences USA 83, 4923-4926.

Chen D, Nylander AG, Norlen P \& Hakanson R (1996) Gastrin does not stimulate growth of the pancreas. Scandinavian Journal of Gastroenterology 31, 404-410.

Chen D, Zhao C-M, Al-Haider W, Hakanson R, Rehfeld JF \& Kopin AS (2002) Differentiation of gastric ECL cells is altered in CCK2 receptor-deficient mice. Gastroenterology $\mathbf{1 2 3}$, $577-585$

Chen D, Zhao C-M, Hakanson R, Samuelson LC, Rehfeld JF \& Friss-Hansen L (2004) Altered control of gastric acid secretion in gastrin-cholecystokinin double mutant mice. Gastroenterology 126, 476-487.

Cheng Z-J, Harikumar KG, Holicky EL \& Miller LJ (2003) Heterodimerization of type A and B cholecystokinin receptors enhance signaling and promote cell growth. Journal of Biological Chemistry 278, 52972-52979.

Chowdhury P \& Rayford PL (2001) Effect of food restriction on plasma cholecystokinin levels and exocrine pancreatic function in rats. Annals of Clinical Laboratory Science 31, 376-382.

Clerc P, Dufresne M, Saillan C, Chastre E, André T, Escrieut C, Kennedy K, Vaysse N, Gespach C \& Fourmy D (1997) Differential expression of the CCK-A and CCK-B/gastrin receptor genes in human cancers of the oesophagus, stomach and colon. International Journal of Cancer 72, 931-936.

Clerc P, Leung-Theung-Long S, Wang TC, Dockray GJ, Bouisson M, Delisle MB, Vaysse N, Pradayrol L, Fourmy D \& Dufresne M (2002) Expression of CCK2 receptors in the murine pancreas: proliferation, transdifferentiation of acinar cells and neoplasia. Gastroenterology 122, 428-437.

Comaru-Schally AM \& Schally AV (1990) LHRH agonists as adjuncts to somatostatin analogs in the treatment of pancreatic cancer. In GnRH Analogues in Cancer and Human Reproduction, vol. III, Benign and Malignant Tumors, pp. 203-210 [BH Vickery and B Lunenfeld, editors]. Boston, MA: Kluwer.

Conwell DL, Zuccaro G, Morrow JB, Van Lente F, O'Laughlin C, Vargo JJ \& Dumot JA (2002) Analysis of duodenal drainage fluid after cholecystokinin (CCK) stimulation in healthy volunteers. Pancreas 25, 350-354.

Cottrell DF \& Iggo A (1984) Mucosal enteroceptors with vagal afferent fibres in the proximal duodenum of sheep. Journal of Physiology 354, 497-522.

Crawley JH (1991) Cholecystokinin-dopamine interactions. Trends in Pharmacological Sciences 12, 232-236.

Crawley JN \& Corwin RL (1994) Biological actions of cholecystokinin. Peptides 15, 731-755.

Danzer M, Jocic M, Samberger C, Painsipp E, Bock E, Pabst MA, Crailsheim K, Schicho R, Lippe IT \& Holzer P (2004) Stomachbrain communication by vagal afferents in response to luminal acid backdiffusion, gastrin, and gastric acid secretion. American Journal of Physiology 286, G403-G411.

Darcel NP, Liou AP, Tome D \& Raybould HE (2005) Activation of vagal afferents in the rat duodenum by protein digests requires PepT1. Journal of Nutrition 135, 1491-1495.

Deng X \& Whitcomb DC (1998) Neurohormonal control of the exocrine pancreas. Current Opinion in Gastroenterology 14, $362-368$.

Desbois C, Huerou-Luron I, Dufresne M, Estival A, Clerc P, Rome V, Clemente F, Guilloteau P \& Fourmy D (1999) The $\mathrm{CCKB} /$ gastrin receptor is coupled to the regulation of enzyme secretion, protein synthesis and p70 S6 kinase activity in acinar cells from ElasCCKB transgenic mice. European Journal of Biochemistry 266, 1003-1010. 
Deschodt-Lanckman M, Bui N, Koulisher D, Paroutaud P \& Strosberg A (1983) Cholecystokinin octa- and tetrapeptide degradation by synaptic membranes. II. Solubilization and separation of membrane-bound CCK8 cleaving enzymes. Peptides 4, 71-78.

Detjen K, Fenrich C \& Logsdon CD (1997) Transfected cholecystokinin receptors mediate growth inhibitory effects on human pancreatic cell lines. Gastroenterology 112, 952-959.

Dockray G, Dimaline R \& Varro A (2005) Gastrin: old hormone, new functions. Pflugers Archiv 449, 344-355.

Dockray GJ (1978) The endocrine versatility of the gut: general and evolutionary aspects of the active peptides of the gastrointestinal tract. Journal of Clininical Pathology 8, 1-6.

Dockray GJ (1999) Gastrin and gastric epithelial physiology. Journal of Physiology 518, 315-324.

Dockray GJ (2004) Clinical endocrinology and metabolism. Gastrin. Baillière's Best Practice and Research. Clinical Endocrinology and Metabolism 18, 555-568.

Dockray GJ, Varro A, Dimaline R \& Wang T (2001) The gastrins: their production and biological activities. Annual Review of Physiology 63, 119-139.

Edkins JS (1905) On the chemical mechanism of gastric secretion. Proceedings of the Royal Society 76B, 376.

Ekelund M, Hakanson R, Hedenbro J, Rehfeld JF \& Sundler F (1985) Endocrine cells and parietal cells in the stomach of the developing rat. Acta Physiologica Scandinavica 124, 483-497.

Evilevitch L, Pierzynowski SG, Linderoth A, Ahren B, ErlansonAlbertsson CH, Podgurniak M \& Westrom BR (2005) Three-day enteral exposure to a red kidney bean lectin preparation enhances the pancreatic response to CCK stimulation in suckling pigs. Biology of the Neonate 87, 20-25.

Feurle GE, Hamscher G \& Firat AE (1995) The role of CCK and its analogues in the organogenesis of the fetal rat pancreas. Pancreas 10, 281-286.

FitzGerald AJ, Ghatei MA, Mandir N, Bloom SR, Iversen L \& Goodlad RA (2002) Effects of amidated gastrin and glycineextended gastrin on cell proliferation and crypt fission in parenterally and orally fed rats. Digestion 66, 58-66.

Folsch UR, Winckler K \& Wormsley KG (1978) Influence of repeated administration of cholecystokinin and secretin on pancreas of the rat. Scandinavian Journal of Gastroenterology 13, 663-671.

Fourmy D, Escrieut C, Archer E, et al. (2002) Structure of cholecystokinin receptor binding sites and mechanism of activation/inactivation by agonists/antagonists. Pharmacology and Toxicology 91, 313-320.

Funakoshi A, Miyasaka K, Jimi A, Kawanai T, Takata Y \& Kono A (1994) Little or no expression of the cholecystokinin-A receptor gene in the pancreas of diabetic rats (Otsuka Long-Evans Tokushima Fatty = OLETF rats). Biochemical and Biophysical Research Communications 199, 482-488.

Funakoshi A, Miyasaka K, Kanai S, Masuda M, Yasunami Y, Nagai T, Ikeda S, Jinu A, Kawanami T \& Kono A (1996) Pancreatic endocrine dysfunction in rats not expressing the cholecystokinin-A receptor. Pancreas 12, 230-236.

Gabryelewicz A, Kulesza E \& Konturek SJ (1990) Comparison of loxiglumide, a cholecystokinin (CCK)-receptor antagonist and atropine on hormonal and meal-stimulated pancreatic secretion in man. Scandinavian Journal of Gastroenterology 25, $731-738$.

Geleva D, Thomas W, Gannon MC \& Keenan JM (2003) A solubilized cellulose fiber decreases peak postprandial cholecystokinin concentrations after a liquid mixed meal in hypercholesterolemic men and women. Journal of Nutrition 133, 2194-2203.
Genton L \& Kudsk KA (2003) Interactions between the enteric nervous system and the immune system: role of neuropeptides and nutrition. American Journal of Surgery 186, 253-258.

Gibbs JRC, Young RC \& Smith GP (1973) Cholecystokinin decreases food intake in rats. Journal of Comparative Physiology and Psychology 84, 488-495.

Glatzle J, Wang Y, Adelson DW, Kalogeris TJ, Zittel TT, Tso P, Wei JY \& Raybould HE (2003) Chylomicron components activate duodenal vagal afferents via a cholecystokinin A receptor-mediated pathway to inhibit gastric motor function in the rat. Journal of Physiology 550, 657-664.

Goetze JP, Nielsen FC, Burcharth F \& Rehfeld JF (2000) Closing the gastrin loop in pancreatic carcinoma, co-expression of gastrin and its receptor in solid human pancreatic adenocarcinoma. Cancer 88, 2487.

Grand RJ, Watkins JB \& Torti FM (1976) Development of the human gastrointestinal tract. A review. Gastroenterology 70, $790-810$.

Greenly GH (1999) Gastrointestinal Endocrinology. Totowa, NJ: Humana Press.

Gregory RA, Dockray GJ, Reeve JR Jr, Shively JE \& Miller C (1983) Isolation from porcine antral mucosa of a hexapeptide corresponding to the $\mathrm{C}$-terminal sequence of gastrin. Peptides $\mathbf{4}$, 319-323.

Gregory RA \& Tracy HJ (1964) The constitution and properties of two gastrins extracted from hog antral mucosa. Gut 5, 103-117.

Gregory RA \& Tracy HJ (1972) Isolation of two "big gastrins" from Zollinger-Ellison tumour tissue. Lancet ii, 797-799.

Gregory RA, Tracy HJ, Harris JI, Runswick MJ, Moore S, Kenner GW \& Ramage R (1979) Minigastrin; corrected structure and synthesis. Hoppe-Seyler's Zeitschrift für physiologische Chemie 360, 73-80.

Guilloteau P, Biernat M, Wolinski J \& Zabielski R (2002) Gut regulatory peptides and hormones of the small intestine. In Biology of Intestine in Growing Animals, pp. 271-324 [R Zabielski, B Gregory and B Westrom, editors]. Amsterdam: Elsevier Science.

Guilloteau P, Chayvialle JA, Le Huërou-Luron I, Mouats A, Durand D, Bernard C, Bauchart D \& Toullec R (1994) Molecular forms, gastro-entero-pancreatic production and hepatic clearance of gastrin and somatostatin in the preruminant calf. Effect of dietary protein. Proceedings of the Nutrition Society 53, 294.

Guilloteau P, Chayvialle JA, Toullec R, Grongnet JF \& Bernard C (1992a) Early-life patterns of plasma gut regulatory peptide levels in calves: effects of the first meals. Biology of the Neonate 61, 103-109.

Guilloteau P, Le Huërou-Luron I, Chayvialle JA, Mouats A, Bernard C, Cuber JC, Burton J, Puigserver A \& Toullec R (1992b) Plasma and tissue levels of digestive regulatory peptides during postnatal development and weaning in the calf. Reproduction Nutrition and Development 32, 285-296.

Guilloteau P, Le Huërou-Luron I, Chayvialle JA, Toullec R, Zabielski R \& Blum JW (1997) Gut regulatory peptides in young cattle and sheep. Journal of Veterinary Medicine 44A, 1-23.

Guilloteau P, Le Huërou-Luron I, Le Dréan G, Gestin M, PhilouzeRomé V, Artiaga A, Bernard C \& Chayvialle JA (1998) Gut regulatory peptide levels in bovine fetuses and their dams between the 3rd and 9th months of gestation. Biology of the Neonate 74, 430-438.

Guilloteau P, Le Huërou-Luron I, Romé V \& Plodari M (1999) Nutrient absorption is related to quantity of pancreatic enzyme secretion: preliminary results. South Africa Journal of Animal Science 29, 241-242.

Guilloteau P, Paruelle JL, Toullec R \& Mathieu CM (1975) Utilization of proteins by preruminant fattening calf. III - 
Gastric emptying as affected by the substitution of milk protein by fish protein (in French). Annales de Zootechnie 24, 243-253. Guilloteau P, Romé V, Le Normand L, Savary G \& Zabielski R (2004) Is Na-butyrate a growth factor in preruminant calf? Preliminary results. Journal of Animal and Feed Sciences 13, Suppl. 1, 393-396.

Guilloteau P \& Zabielski R (2005a) Gut regulatory peptides as mediators of gastrointestinal tract growth, motility and development of secretion in young ruminants. Journal of Animal and Feed Sciences 14, Suppl. 1, 113-138.

Guilloteau P \& Zabielski R (2005b) Digestive secretions in preruminant and ruminant calves and some aspects of their regulation. In Calf and Heifer Rearing. Principles of Rearing the Modern Dairy Heifer from Calf to Calving, pp. 159-189 [P Garnsworthy, editor]. Nottingham: Nottingham University Press.

Guilmeau S, Buyse M, Tsocas A, Laigneau JP \& Bado A (2003) Duodenal leptin stimulates cholecystokinin secretion: evidence of a positive leptin-cholecystokinin feedback loop. Diabetes $\mathbf{5 2}$, 1664-1672.

Gukovskaya AS, Gukovsky I, Jung Y, Mouria M \& Pandol SJ (2002) Cholecystokinin induces caspase activation and mitochondrial dysfunction in pancreatic acinar cells. Roles in cell injury processes of pancreatitis. Journal of Biological Chemistry 277, 22595-22604.

Haigh CR, Attwood SEA, Thompson DG, Jankowski JA, Kirton CM, Pritchard DM, Varro A \& Dimaline R (2003) Gastrin induces proliferation in Barrett's metaplasia through activation of the CCK2 receptor. Gastroenterology 124, 615-625.

Häkanson R \& Rehfeld JF (2002) A centennial celebration of gastrointestinal endocrinology: structure and function of gastrin/cholecystokinin receptors. Pharmacology and Toxicology 91, 273-274.

Hall WL, Millward DJ, Long SL \& Morgan LM (2003) Casein and whey exert different effects on plasma amino acid profiles, gastrointestinal hormone secretion and appetite. British Journal of Nutrition 89, 239-248.

Harper AA \& Raper HS (1943) Pancreozymin, a stimulant of the secretion of pancreatic enzymes in extracts of the small intestine. Journal of Physiology 102, 115-125.

Havu N (1986) Enterochromaffin-like cells carcinoids of gastric mucosa in rats after life-long inhibition of gastric secretion. Digestion 35, 42-55.

Herranz R (2003) Cholecystokinin antagonists: pharmacological and therapeutic potential. Medical Research Review 23, 559-605.

Hirschowitz BI \& Molina E (1983) Relation of gastric acid and pepsin secretion to serum gastrin levels in dogs given bombesin and gastrin-17. American Journal of Physiology 244, G546-G551.

Hopman WP, de Jong AJ, Rosenbusch G, Jansen JB \& Lamers CB (1987) Elemental diet stimulates gallbladder contraction and secretion of cholecystokinin and pancreatic polypeptide in man. Digestive Diseases and Sciences 32, 45-49.

Hopman WP, Jansen JB \& Lamers CB (1984a) Plasma cholecystokinin response to a liquid fat meal in vagotomized patients. Annals of Surgery 200, 693-697.

Hopman WP, Jansen JB \& Lamers CB (1984b) Plasma cholecystokinin response to oral fat in patients with Billroth I and Billroth II gastrectomy. Annals of Surgery 199, 276-280.

Hosotani R, Chowdhury P, McKay D \& Rayford PL (1987) L364718, a new CCK angatonist, inhibits biological actions of CCK in conscious dogs. Peptides 8, 1061-1064.

Ikeda Y \& Fukuoka S (2003) Phosphatidic acid production, required for cholecystokinin octapeptide-stimulated amylase secretion from pancreatic acinar AR42J cells, is regulated by a wortmannin-sensitive process. Biochemical and Biophysical Research Communications 306, 943-947.

Inoue K, Ayalon A, Yazigi R, Watson C, Rayford PL \& Thompson JC (1982) Removal of circulating gastrin and cholecystokinin into the lumen of the small intestine. Digestion 24, 118-125.

Ivy AC \& Oldberg A (1928) A hormone mechanism for gallbladder contraction and evacuation. American Journal of Physiology 86, 599-613.

Iwai K, Fukuoka S, Fushiki T, Kodaira T \& Ikei N (1986) Elevation of plasma CCK concentration after intestinal administration of a pancreatic enzyme secretion-stimulating peptide purified from rat bile-pancreatic juice: analysis with $\mathrm{N}$-terminal region specific radioimmunoassay. Biochemical and Biophysical Research Communications 136, 701-706.

Iwase M, Uchizono Y, Nakamura U, Nohara S \& Iida M (2003) Effect of exogenous cholecystokinin on islet blood flow in anesthetized rats. Regulatory Peptides 116, 87-93.

Jensen RT (2002) Involvement of cholecystokinin/gastrin-related peptides and their receptors in clinical gastrointestinal disorders. Pharmacology and Toxicology 91, 333-950.

Jensen RT, Wank SA, Rowley WH, Sato S \& Gardner JD (1989) Interactions of cholecystokinin with pancreatic acinar cells: a well-studied model of peripheral action of CCK. Trends in Pharmacological Sciences 10, 418-423.

Ji B, Bi Y, Simeone D, Mortensen RM \& Logsdon CD (2001) Human pancreatic acinar cells lack functional responses to cholecystokinin and gastrin. Gastroenterology 121, 1380-1390.

Ji B, Bi Y, Simeone D, Mortensen RM \& Logsdon CD (2002) Human pancreatic acinar cells do not respond to cholecystokinin. Pharmacology and Toxicology 91, 327-332.

Ji B, Kopin AS \& Logsdon CD (2000) Species differences between rat and mouse CCKA receptors determine the divergent acinar cell response to the cholecystokinin analog JMV-180. Journal of Biological Chemistry 275, 19115-19120.

Ji TH, Grossmann M \& Ji I (1998) G protein-coupled receptors. I. Diversity of receptor-ligand interactions. Journal of Biological Chemistry 273, 17299-17302.

Johnson LR (1976) The trophic action of gastrointestinal hormones. Gastroenterology 70, 278-288.

Johnson LR (1981) Effects of gastrointestinal hormones on pancreatic growth. Cancer 47, 1640-1645.

Jordan PH Jr \& Yip BS (1972) The presence of gastrin in fasting and stimulated gastric juice of man. Surgery 72, 352-356.

Jorpes JE \& Mutt V (1966) Cholecystokinin and pancreozymin: one single hormone? Acta Physiologica Scandinavica 66, 196.

Jurkowska G, Grondin G, Massé S \& Morisset J (1992a) Soybean trypsin inhibitor and caerulein accelerate recovery of caeruleininduced pancreatitis in rats. Gastroenterology 102, 550-562.

Jurkowska G, Grondin G \& Morisset J (1992b) Involvement of endogenous cholecystokinin in pancreatic regeneration after caerulein-induced acute pancreatitis. Pancreas 7, 295-304.

Kanayama S \& Liddle RA (1991) Regulation of intestinal cholecystokinin and somatostatin mRNA by bombesin in rats. American Journal of Physiology 261, G71-G77.

Karlsson S \& Ahren B (1992) CCK8-stimulated insulin secretion in vivo is mediated by CCK-A receptors. European Journal of Pharmacology 213, 145-146.

Kawano K, Hirashima T, Mori S, Saitoh Y \& Kurosumi M (1992) Spontaneous long-term hyperglycemic rat with diabetic complications. Diabetes 41, 1422-1428.

Kiba T, Tanaka K, Numata K, Hoshino M, Misugi K \& Inoue S (1996) Ventromedial hypothalamic lesion-induced vagal hyperactivity stimulates rat pancreatic cell proliferation. Gastroenterology 110, 885-893.

Kiela P, Zabielski R, Podgurniak P, Midura M, Barej W, Gregory PC \& Pierzynowski SG (1996) Cholecystokinin-8 and vasoactive intestinal polypeptide stimulate exocrine pancreatic 
secretion via duodenal mediated mechanisms in the conscious pig. Experiencia Physiologica 81, 375-384.

Koide M, Okabayashi Y \& Otsuki M (1993) Role of endogenous bile on basal and postprandial CCK release in humans. Digestive Diseases and Science 38, 1284-1290.

Konturek SJ, Bilski J, Konturek PK, Cieszkowski M \& Pawlik W (1993) Role of endogenous nitric oxide in the control of canine pancreatic secretion and blood flow. Gastroenterology 104, 896-902.

Konturek SJ, Konturek PC, Bielanski W, Karczewska E, Zuchowicz M, Hartwich A, Rehfeld JF, Goetze JP \& Hahn EG (2003a) Serum progastrin and its products, gastric acid secretion and serum pepsinogen $\mathrm{I}$ in gastric cancer. Digestion 68, $169-177$

Konturek SJ, Szlachcic A, Dembiński A, Warzecha Z, Jaworek J \& Stachura J (1994) Nitric oxide in pancreatic secretion and hormone-induced pancreatitis in rats. International Journal of Pancreatology 15, 19-28.

Konturek SJ, Tasler J, Bilski J, de Jong AJ, Jansen JB \& Lamers CB (1986a) Physiological role and localization of cholecystokinin release in dogs. American Journal of Physiology 250, G391-G397.

Konturek SJ, Tasler J \& Obtulowicz W (1972) Localization of cholecystokinin release in intestine of the dog. American Journal of Physiology 222, G16-G22.

Konturek SJ, Thor PJ, Bilski J, Bielański W \& Laskiewicz J (1986b) Relationships between duodenal motility and pancreatic secretion in fasted and fed dogs. American Journal of Physiology 250, G570-G574.

Konturek SJ, Zabielski R, Konturek JW \& Czarnecki J (2003b) Neuroendocrinology of the pancreas; role of brain-gut axis in pancreatic secretion. European Journal of Pharmacology 481, $1-14$.

Kopin AS, Lee Y, McBride EW, Miller LJ, Lu M, Lin HY, Kolakowski LF \& Beinborn M (1992) Expression, cloning and characterization of the canine parietal cell gastrin receptor. Proceedings of the National Academy of Sciences USA 89, 3605-3609.

Kopin AS, McBride EW, Schaffer K \& Beinborn M (2000) CCK receptor polymorphisms: an illustration of emerging themes in pharmacogenomics. Trends in Pharmacological Sciences 21, 346-353.

Krishnamurthy S, Cerulli-Switzer J, Chapman N \& Krishnamurthy GT (2003) Comparison of gallbladder function obtained with regular CCK8 and pharmacy-compounded CCK8. Journal of Nuclear Medicine 44, 499-504.

Krishnamurthy S \& Krishnamurthy GT (1997) Biliary dyskinesia: role of the sphincter of Oddi, gallbladder and cholecystokinin. Journal of Nuclear Medicine 38, 1824-1830.

Kurosawa M, Uvnas-Moberg K, Miyasaka K \& Lundeberg T (1997) Interleukin-1 increases activity of the gastric vagal afferent nerve partly via stimulation of type A CCK receptor in anesthetized rats. Journal of the Autonomic Nervous System $\mathbf{6 2}$, $72-78$.

Lacourse KA, Swanberg LJ, Gillespie PJ, Rehfeld JF, Saunders TL \& Samuelson LC (1999) Pancreatic function in CCK-deficient mice: adaptation to dietary protein does not require CCK. American Journal of Physiology 276, G1302-G1309.

Lal S, Kirkup AJ, Brunsden AM, Thompson DG \& Grundy D (2001) Vagal afferent responses to fatty acids of different chain length in the rat. American Journal of Physiology 281, G907-G915.

Lal S, McLaughlin J, Barlow J, D’Amato M, Giacovelli G, Varro A, Dockray GJ \& Thompson DG (2004) Cholecystokinin pathways modulate sensations induced by gastric distension in humans. American Journal of Physiology 287, G72-G79.
Langhans N, Rindi G, Chiu M, Rehfeld JF, Ardman B, Beinborn M \& Kopin AS (1997) Abnormal gastric histology and decreased acid production in cholecystokinin-B/gastrin receptor-deficient mice. Gastroenterology 112, 280-286.

Larsson LI \& Rehfeld JF (1978) Distribution of gastrin and CCK cells in the rat gastrointestinal tract. Evidence for the occurrence of three distinct cell types storing $\mathrm{COOH}$-terminal gastrin immunoreactivity. Histochemistry 58, 23-31.

Laster L \& Walsh JH (1968) Enzymatic degradation of C-terminal tetrapeptide amide of gastrin by mammalian tissue extracts. Federation Proceedings 27, 1328-1330.

Le Dréan G, Le Huërou-Luron I, Chayvialle JA, Philouze-Romé V, Gestin M, Bernard C, Toullec R \& Guilloteau P (1997) Kinetics of pancreatic exocrine secretion and plasma gut regulatory peptide release in response to feeding in preruminant and ruminant calves. Comparative Biochemistry and Physiology 117A, 245-255.

Le Dréan G, Le Huërou-Luron I, Gestin M, Romé V, Plodari M, Bernard C, Chayvialle JA \& Guilloteau P (1998) Comparison of the kinetics of pancreatic secretion and gut regulatory peptides in the plasma of preruminant calves fed milk or soyabean protein. Journal of Dairy Science 81, 1313-1321.

Lefranc F, Mijatovic T, Mathieu V, Rorive S, Decaestecker C, Debeir O, Brotchi J, Van Ham P, Salmon I \& Kiss R (2004) Characterization of gastrin-induced proangiogenic effects in vivo in orthotopic U373 experimental human glioblastomas and in vitro in human umbilical vein endothelial cells. Clinical Cancer Research 24, 8250-8265.

Lefranc F, Sadeghi N, Metens T, Brotchi J, Salmon I \& Kiss R (2003) Characterization of gastrin-induced cytostatic effect on cell proliferation in experimental malignant gliomas. Neurosurgery 52, 881-890.

Lehmann FS, Golodner EH, Wang J, Chen MC, Avedian D, Calam J, Walsh JH, Dubinett S \& Soll AH (1996) Mononuclear cells and cytokines stimulate gastrin release from canine antral cells in primary culture. American Journal of Physiology 270, G783-G788.

Le Huërou-Luron I, Gestin M, Le Dréan G, Romé V, Bernard C, Chayvialle JA \& Guilloteau P (1998) Source of dietary protein influences kinetics of plasma gut regulatory peptide concentration in response to feeding in preruminant calves. Comparative Biochemistry and Physiology 119A, 817-824.

Lehy T, Bonnefond A, Dubrasquet M, Nasca S, Lewin M \& Bonfils S (1973) Comparative effects of antrocolic transposition and antrectomy on fundic mucosa and acid secretion of the rat. Gastroenterology 64, 421-428.

Le Meuth V, Philouze-Rome V, Le Huërou-Luron I, Formal M, Vaysse N, Gespach C, Guilloteau P \& Fourmy D (1993) Differential expression of A- and B-subtypes of cholecystokinin/gastrin receptors in the developing calf pancreas. Endocrinology 133, 1182-1191.

Leray V, Segain JP, Cherbut C \& Galmiche JP (2003) Adaptation to low-protein diet increases inhibition of gastric emptying by CCK. Peptides 24, 1929-1934.

Levi S, Beardshall K, Swift I, Foulkes W, Playford R, Ghosh P \& Calam J (1989) Antral Campylobacter pylori, hypergastrinemia, and duodenal ulcers: effect of eradicating the organism. British Medical Journal 299, 1504-1505.

Lhoste EF, Fiszlewicz M \& Corring T (2002) Administration of two antagonists of the cholecystokinin(B)/gastrin receptor does not totally inhibit the pancreatic response to a meal in the pig. Pancreas 24, 47-52.

Li Y \& Owyang C (1993) Vagal afferent pathway mediates physiological action of cholecystokinin on pancreatic enzyme secretion. Journal of Clinical Investigation 92, 418-424. 
Li Y \& Owyang C (1994) Endogenous cholecystokinin stimulates pancreatic enzyme secretion via vagal afferent pathway in rats. Gastroenterology 107, 525-531.

Liddle RA (1994) Cholecystokinin. In Gut Peptides, pp. 175-216 [JH Walsh and GJ Dockray, editors]. New York: Raven Press.

Liddle RA (1997) Cholecystokinin cells. Annual Review of Physiology 59, 221-242.

Liddle RA (2000) Regulation of cholecystokinin secretion in humans. Journal of Gastroenterology 35, 181-187.

Liddle RA, Elashoff J \& Reeve JR Jr (1986) Relative bioactivities of cholecystokinins- 8 and -33 on rat pancreatic acini. Peptides $\mathbf{7}$, $723-727$.

Liddle RA, Gertz BJ, Kamayama S, Beccaria L, Coker LD, Turnbull TA \& Marita ET (1989) Effects of a novel cholecystokinin (CCK) receptor antagonist, MK-329, on gallbladder contraction and gastric emptying in humans: implications for the physiology of CCK. Journal of Clinical Investigation 84, 1220-1225.

Liddle RA, Gertz BJ, Kanayama S, Beccaria L, Gettys TW, Taylor IL, Rushakoff RJ, Williams VC \& Coker LD (1990) Regulation of pancreatic endocrine function by cholecystokinin: studies with MK-329, a nonpeptide cholecystokinin receptor antagonist. Journal of Clinical Endocrinology and Metabolism 70, $1312-1318$.

Liddle RA, Goldfine ID, Rosen MS, Taplitz RA \& Williams JA (1985) Cholecystokinin bioactivity in human plasma. Molecular forms, responses to feeding, and relationship to gallbladder contraction. Journal of Clinical Investigation 75, 1144-1152.

Liddle RA, Goldfine ID \& Williams JA (1984) Bioassay of plasma cholecystokinin in rats: effects of food, trypsin inhibitor, and alcohol. Gastroenterology 87, 542-549.

Lin CW \& Miller TR (1992) Both CCK-A and CCK-B/gastrin receptors are present on rabbit vagus nerve. American Journal of Physiology 263, R591-R595.

Lindström E, Chen D, Norlen P, Andersson K \& Hakanson R (2001) Control of gastric acid secretion: the gastrin-ECL cellparietal cell axis. Comparative Biochemistry and Physiology 128A, 505-514.

Lippl F, Kircher F, Erdmann J, Allescher HD \& Schusdziarra V (2004) Effect of GIP, GLP-1, insulin and gastrin on ghrelin release in the isolated rat stomach. Regulatory Peptides 119, 93-98.

Lloyd KC, Raybould HE \& Walsh JH (1992) Cholecystokinin inhibits gastric acid secretion through type "A" cholecystokinin receptors and somatostatin in rats. American Journal of Physiology 263, G287-G292.

Lloyd KC, Wang J \& Solomon TE (2001) Acid inhibition by intestinal nutrients mediated by CCK-A receptors but not plasma CCK. American Journal of Physiology 281, G924-G930.

Logsdon CD (1986) Stimulation of pancreatic acinar cell growth by CCK, epidermal growth factor, and insulin in vitro. American Journal of Physiology 251, G487-G494.

Lu L, Louie D \& Owyang C (1989) A cholecystokinin releasing peptide mediates feedback regulation of pancreatic secretion. American Journal of Physiology 256, G430-G435.

McQueen K, Kovac S, Ho PK, Rorison K, Pannequin J, Neumann G, Shulkes A \& Baldwin GS (2002) Preparation of biologically active recombinant human progastrin $(1-80)$. Journal of Protein Chemistry 21, 465-471.

McWilliams DF, Watson SA, Crosbee DM, Michaeli D \& Seth R (1998) Coexpression of gastrin and gastrin receptors (CCK-B and delta CCK-B) in gastrointestinal tumour cell lines. Gut $\mathbf{4 2}$, $795-798$.

Magee DF \& Naruse S (1983) Neural control of periodic secretion of the pancreas and the stomach in fasting dogs. Journal of Physiology 344, 153-160.
Magee DF \& Naruse S (1988) The effect of cholecystokininrelated peptides on periodic pancreatic secretion in fasting dogs. Journal of Physiology 403, 15-25.

Martin F, MacLoed IB \& Sircus W (1970) Effects of antrectomy on the fundic mucosa of the rat. Gastroenterology 59, 437-444.

Maton PN, Selden AC \& Chadwick VS (1984) Differential distribution of molecular forms of cholecystokinin in human and porcine small intestinal mucosa. Regulatory Peptides 8, 9-19.

Matyjek R, Herzig KH, Kato S \& Zabielski R (2003) Exogenous leptin inhibits the secretion of pancreatic juice via a duodenal CCK1-vagal-dependent mechanism in anaesthetized rats. Regulatory Peptides 114, 15-20.

Mawe GM (1998) Nerves and hormones interact to control gallbladder function. News in Physiological Sciences 13, 84-90.

Miller LJ, Holicky EL, Ulrich CD \& Wieben ED (1995) Abnormal processing of the human cholecystokinin receptor gene in association with gallstones and obesity. Gastroenterology 109, $1375-1380$

Miyasaka K \& Funakoshi A (2003) Cholecystokinin and cholecystokinin receptors. Journal of Gastroenterology 38, $1-13$.

Miyasaka K, Guan DF, Liddle RA \& Green GM (1989) Feedback regulation by trypsin: evidence for intraluminal CCK-releasing peptide. American Journal of Physiology 257, G175-G181.

Miyasaka K, Kanai S, Ohta M \& Funakoshi A (1997a) Aging impairs release of central and peripheral cholecystokinin (CCK) in male but not in female rats. Journal of Gerontology 52A, M14-M18.

Miyasaka K, Masuda M, Kawanami T \& Funakoshi A (1996) Neurohormonal regulation of pancreatic exocrine function in rats without gene expression of the cholecystokinin-A receptor. Pancreas 12, 272-279.

Miyasaka K, Ohta M, Masuda M \& Funakoshi A (1997b) Retardation of pancreatic regeneration after partial pancreatectomy in a strain of rats without CCK-A receptor gene expression. Pancreas 14, 391-399.

Miyasaka K, Shinozaki H, Jimi A \& Funakoshi A (2002) Amylase secretion from dispersed human pancreatic acini: neither cholecystokinin nor cholecystokinin B receptors mediate amylase secretion in vitro. Pancreas 25, 161-165.

Miyasaka K, Suzuki S, Kanai S, Masuda M \& Funakoshi A (1999) Role of CCK-A receptor in the regulation of pancreatic bicarbonate secretion in conscious rats: a study in naturally occurring CCK-A receptor gene knockout rats. Pancreas 3, 217-223.

Modlin IM \& Tang LH (1996) The gastric enterochromaffin-like cell: an enigmatic cellular link. Gastroenterology 111, 783-810.

Moriarty P, Dimaline R, Thompson DG \& Dockray GJ (1997) Characterization of cholecystokininA and cholecystokininB receptors expressed by vagal afferent neurons. Neuroscience $\mathbf{7 9}$, 905-913.

Morisset J \& Calvo E (1998) Trophicity of the pancreas from rodents to man. Journal of Physiology and Pharmacology 49, Suppl. 2, 25-37.

Morisset J, Guan D, Jurkowska G, Rivard N \& Green GM (1992) Endogenous cholecystokinin, the major factor responsible for dietary protein-induced pancreatic growth. Pancreas 7, $522-529$.

Morisset J, Julien S \& Lainé J (2003) Localisation of cholecystokinin receptor subtypes in the endocrine pancreas. Journal of Histochemistry and Cytochemistry 51, 1501-1513.

Morisset J, Lainé J, Biernat M \& Julien S (2004) What are the pancreatic target cells for gastrin and its CCKB receptors? Is it a couple for cancerous cells? Medical Science Monitor 10, RA242-RA246. 
Morisset J, Lainé J \& Mimeau-Worthington T (1999) Hormonal control of rat fetal pancreas development. Biology of the Neonate 75, 327-336.

Morisset J, Levenez F, Corring T, Benrezzak O, Pelletier G \& Calvo E (1996) Pig pancreatic acinar cells possess predominantly the $\mathrm{CCK}_{\mathrm{B}}$ receptor subtype. American Journal of Physiology 271, E397-E402.

Morisset J, Morisset S, Lauzon K, Côté S, Lainé J, Bourassa J, Lessard M \& Echavé V (2000a) Pancreatic inflammation, apoptosis and growth: sequential events after partial pancreatectomy in pigs. Pancreas 21, 321-325.

Morisset J, Wong H, Walsh JH, Lainé J \& Bourassa J (2000b) Pancreatic $\mathrm{CCK}_{\mathrm{B}}$ receptors: their potential roles in somatostatin release and $\delta$-cell proliferation. American Journal of Physiology 279, G148-G156.

Morton MF, Welsh NJ, Tavares IA \& Shankley NP (2002) Pharmacological characterization of cholecystokinin receptors mediating contraction of human gallbladder and ascending colon. Regulatory Peptides 105, 59-64.

Naito Y, Ito M, Watanabe T \& Suzuki H (2005) Biomarkers in patients with gastric inflammation: a systematic review. Digestion 72, 164-180.

Niederau C \& Karaus M (1991) Effects of CCK receptor blockade on intestinal motor activity in conscious dogs. American Journal of Physiology 260, G315-G324.

Noble F, Wank SA, Crawley JN, Bradwejn J, Seroogy KB, Hamon M \& Roques BP (1999) International Union of Pharmacology. XXI. Structure, distribution, and functions of cholecystokinin receptors. Pharmacological Reviews 51, 745-781.

Ohlsson B, Borg K, Rehfeld JF, Axelson J \& Sundler F (2001) The method of administration of cholecystokinin determines the effects evoked in the pancreas. Pancreas 23, 94-101.

Ohta M, Tanaka Y, Masuda M, Miyasaka K \& Funakoshi A (1995) Impaired release of cholecystokinin (CCK) from synaptosomes in old rats. Neuroscience Letters 6, 161-164.

Ohumura T, Shoji E, Onodera S \& Kohgo Y (1996) Susceptibility to the development of gastric mucosal damage in OLETF rat not expressing the CCK-A receptor. Biochemical and Biophysical Research Communications 224, 728-733.

O'Keefe SJ, Lee RB, Anderson FP, Gennings C, Abou-Assi S, Clore J, Heuman D \& Chey W (2003) Physiological effects of enteral and parenteral feeding on pancreaticobiliary secretion in humans. American Journal of Physiology 284, G27-G36.

Okumiya K, Matsubayashi K, Maeda T \& Fujimiya M (1996) Change in subcellular localization of gastrin-like immunoreactivity in epithelial cells of rat duodenum induced by carbachol. Peptides 17, 225-232.

Olsson C \& Holmgren S (2001) The control of gut motility. Comparative Biochemistry and Physiology 128A, 481-503.

Otsuki M (2000) Pathophysiological role of cholecystokinin in humans. Journal of Gastroenterology and Hepatology 15, Suppl., D71-D83.

Owyang C (1996) Physiological mechanisms of cholecystokinin action on pancreatic secretion. American Journal of Physiology 271, G1-G7.

Palmer-Smith J, Liu G, Soundararajan V, McLaughlin PJ \& Zagon IS (1994) Identification and characterization of CCK-B/gastrin receptors in human pancreatic cancer cell lines. American Journal of Physiology 266, R277-R283.

Parkin DM, Bray F, Ferlay J \& Pisani P (2005) Global cancer statistics, 2002. CA: A Cancer Journal for Clinicians 55, 74-108.

Pfefferkorn MD, Fitzgerald JF, Croffie JM, Gupta SK \& Caffrey HM (2002) Direct measurement of pancreatic enzymes: a comparison of secretagogues. Digestive Diseases and Sciences 47, 2211-2216.
Philippe C, Lhoste EF, Dufresne M, Moroder L, Corring T \& Fourmy D (1997) Pharmacological and biochemical evidence for the simultaneous expression of $\mathrm{CCKB} /$ gastrin and CCKA receptors in the pig pancreas. British Journal of Pharmacology 120, 447-454.

Pierzynowski SG, Mårtensson H, Ahrén B \& Weström BR (1991) Differences in the effects of CCK on porcine pancreatic secretion after administration into the jugular vein or into duodenal artery. Digestion 49, Suppl. 1, 60-68.

Polak J, Pearse A, Bloom S, Buchan A, Rayford P \& Thompson J (1975) Identification of cholecystokinin-secreting cells. Lancet ii, $1016-1021$.

Praissman M \& Izzo RS (1986) A reduced pancreatic protein secretion in response to cholecystokinin (CCK) in the obese Zucker rat correlates with a reduced receptor capacity for CCK. Endocrinology 119, 546-553.

Prinz C, Zanner R \& Gratzl M (2003) Physiology of gastric enterochromaffin-like cells. Annual Review of Physiology 65, $371-382$

Reeve JR Jr, Green GM, Chew P, Eysselein VE \& Keire DA (2003a) CCK-58 is the only detectable endocrine form of cholecystokinin in rat. American Journal of Physiology 285, G255-G265.

Reeve JR Jr, Keire DA, Coskun T, Green GM, Evans C, Ho FJ, Lee TD, Davis MT, Shively JE \& Solomon TE (2003b) Synthesis of biologically active canine CCK-58. Regulatory Peptides 113, $71-77$.

Reeve JR Jr, Liddle RA, McVey DC, Vigna SR, Solomon TE, Keire DA, Rosenquist G, Shively JE, Lee TD, Chew P, Green GM \& Coskun T (2004a) Identification of nonsulfated cholecystokinin58 in canine intestinal extracts and its biological properties. American Journal of Physiology 287, G326-G333.

Reeve JR Jr, Wu SV, Keire DA, Faull K, Chew P, Solomon TE, Green GM \& Coskun T (2004b) Differential bile-pancreatic secretory effects of CCK-58 and CCK8. American Journal of Physiology 286, G395-G402.

Rehfeld JF (1998a) Accurate measurement of cholecystokinin in plasma. Clinical Chemistry 44, 991-1001.

Rehfeld JF (1998b) The new biology of gastrointestinal hormones. Physiological Review 78, 1087-1108.

Rehfeld JF (2004) Clinical endocrinology and metabolism. Cholecystokinin. Best Practices in Research, Clinical Endocrinology and Metabolism 18, 569-586.

Rehfeld JF, Bungaard JR, Friis-Hansen L \& Goetze JP (2003) On the tissue-specific processing of procholecystokinin in the brain and gut - a short review. Journal of Physiology and Pharmacology 54, Suppl. 4, 73-79.

Rehfeld JF \& Johnsen AH (1994) Identification of gastrin component I as gastrin-71: the largest possible bioactive progastrin product. European Journal of Biochemistry 223, $765-773$.

Rehfeld JF \& van Solinge WW (1994) The tumor biology of gastrin and cholecystokinin. Advances in Cancer Research 63, 295-346.

Reubi JC, Schaer JC \& Waser B (1997) Cholecystokinin (CCK)-A and CCK-B/gastrin receptors in human tumors. Cancer Research 57, 1377-1386.

Reubi JC, Waser B, Gugger M, Friess H, Kleeff J, Kayed H, Buchler MW \& Laissue JA (2003) Distribution of CCK1 and CCK2 receptors in normal and diseased human pancreatic tissue. Gastroenterology 125, 98-106.

Richards W, Hillsley K, Eastwood C \& Grundy D (1996) Sensitivity of vagal mucosal afferents to cholecystokinin and its role in afferent signal transduction in the rat. Journal of Physiology 497, 473-481.

Rivard N, Guan D, Maouyo D, Grondin G, Bérubé FL \& Morisset J (1991) Endogenous cholecystokinin release responsible for 
pancreatic growth observed after pancreatic juice diversion. Endocrinology 129, 2867-2874.

Roche S, Gusdinar T, Bali JP \& Magous R (1991) Gastrin and CCK receptors on histamine and somatostatin-containing cells from rabbit fundic mucosa II. Characterization by means of selective antagonists (L-364,718 and L-365,260). Biochemistry and Pharmacology 42, 771-776.

Romanski KW (2004) Ovine model for clear-cut study on the role of cholecystokinin in antral, small intestinal and gallbladder motility. Polish Journal of Pharmacology 56, 247-256.

Rosseti L, Shulman GI \& Zawalich WS (1987) Physiological role of cholecystokinin in meal-induced insulin secretion in conscious rats. Studies with L-364,718, a specific inhibitor of CCK-receptor binding. Diabetes 36, 1212-1215.

Rozengurt E \& Walsh JH (2001) Gastrin, CCK, signaling, and cancer. Annual Review of Physiology 63, 49-76.

Saillan-Barreau C, Dufresne M, Clerc P, et al. (1999) Evidence for a functional role of the cholecystokinin-B/gastrin receptor in the human fetal and adult pancreas. Diabetes 48, 2015-2021.

Saluja AK, Lu L, Yamaguchi Y, Hofbauer B, Runzi M, Dawra R, Bhatia M \& Steer ML (1997) A cholecystokinin-releasing factor mediates ethanol-induced stimulation of rat pancreatic secretion. Journal of Clinical Investigation 99, 506-512.

Sanchez-Fernandez C, Gonzalez MC, Beart PM, Mercer LD, RuizGayo M \& Fernandez-Alfonso MS (2004) A novel role for cholecystokinin: regulation of mesenteric vascular resistance. Regulatory Peptides 121, 145-153.

Sankaran H, Goldfine ID, Bailey A, Licko V \& Williams JA (1982) Relationship of cholecystokinin receptor binding to regulation of biological function in pancreatic acini. American Journal of Physiology 242, G250-G257.

Sayegh AI \& Ritter RC (2003) Cholecystokinin activates specific enteric neurons in the rat small intestine. Peptides 24, 237-244.

Schally AV, Szepeshazi K, Nagy A, Comaru-Schally AM \& Halmos G (2004) New approaches to therapy of cancers of the stomach, colon and pancreas based on peptide analogs. Cellular and Molecular Life Sciences 61, 1042-1068.

Schjoldager B, Molero X \& Miller LJ (1989) Functional and biochemical characterization of the human gallbladder muscularis cholecystokinin receptor. Gastroenterology 96, $1119-1125$

Schmidt PT, Hansen L, Hilsted L \& Holst JJ (2004) Cholecystokinin inhibits gastrin secretion independently of paracrine somatostatin secretion in the pig. Scandinavian Journal of Gastroenterology 39, 217-221.

Schmidt WE, Schenk S, Nustede R, Holst JJ, Folsch UR \& Creutzfeldt W (1994) Cholecystokinin is a negative regulator of gastric acid secretion and postprandial release of gastrin in humans. Gastroenterology 107, 1610-1620.

Schmidt WE \& Schmitz F (2004) Genetic dissection of the secretory machinery in the stomach. Gastroenterology 126, 606-609.

Schnall SF \& Macdonald JS (1991) Adjuvant therapy in colorectal carcinoma. Seminars in Oncology 18, 560-570.

Schneider DA \& Sayegh AI (2002) Gastrointestinal neuroendocrinology. Veterinary Clinics of North America. Equine Practice 18, 205-217.

Schonhoff SE, Giel-Moloney M \& Leiter AB (2004) Minireview: development and differentiation of gut endocrine cells. Endocrinology 145, 2639-2644.

Schweiger M, Erhard MH \& Amselgruber WM (2000) Cell specific localization of the cholecystokinin A receptor in the porcine pancreas. Anatomy, Histology and Embryology 29, 357-361.

Seensalu R, Avedian D, Barbuti R, Song M, Slice L \& Walsh JH (1997) Bombesin-induced gastrin release from canine $\mathrm{G}$ cells is stimulated by $\mathrm{Ca}^{2+}$ but not by protein kinase $\mathrm{C}$, and is enhanced by disruption of rho/cytoskeletal pathways. Journal of Clinical Investigation 100, 1037-1046.

Shulkes A, Chick P \& Hardy KJ (1984) Presence and stability of gastrin in the gastric juice of the fetal sheep. Clinical Experimentation in Pharmacology and Physiology 11, 45-52.

Silen ML \& Gardner JD (1993) Gastrointestinal peptides and cancer. Trends in Endocrinology and Metabolism 4, 131-135.

Silvente-Poirot S, Dufresne M, Vaysse N \& Fourmy D (1993) The peripheral cholecystokinin receptors. European Journal of Biochemistry 215, 513-529.

Singh P, Lu X, Cobb S, Miller BT, Tarasova N, Varro A \& Owlia A (2003) Progastrin P $_{1-80}$ stimulates growth of intestinal epithelial cells in vitro via high-affinity binding sites. American Journal of Physiology 284, G328-G339.

Singh P, Velasco M, Given R, Varro A \& Wang TC (2000) Progastrin expression predisposes mice to colon carcinomas and adenomas in response to a chemical carcinogen. Gastroenterology 119, 162-171.

Smith JP, Stanley WB, Verderame MF \& Zagon IS (2004) The functional significance of the cholecystokinin-C (CCK-C) receptor in human pancreatic cancer. Pancreas 29, 271-277.

Smith JP, Verderame MF, McLaughlin P, Martenis M, Ballard E \& Zagon IS (2002) Characterization of the CCK-C (cancer) receptor in human pancreatic cancer. International Journal of Molecular Medicine 10, 689-694.

Snow ND, Prpic V, Mangel AW, Sharara AI, McVey DC, Hurst LJ, Vigna SR \& Liddle RA (1994) Regulation of cholecystokinin secretion by bombesin in STC-1 cells. American Journal of Physiology 267, G859-G865.

Solomon TE, Petersen H, Elashoff J \& Grossman MI (1978) Interaction of caerulein and secretin on pancreatic size and composition in rat. American Journal of Physiology 235, E714-E719.

Solomon TE, Vanier M \& Morisset J (1983) Cell site and time course of DNA synthesis in pancreas after caerulein and secretin. American Journal of Physiology 245, G99-G105.

Sonobe K, Sakai T, Satoh M, Haga N \& Itoh Z (1995) Control of gallbladder contractions by cholecystokinin through cholecystokinin A receptors in the vagal pathway and gallbladder in the dog. Regulatory Peptides 60, 33-46.

Spannagel AW, Green GM, Guan D, Liddle RA, Faull K \& Reeve JR Jr (1996) Purification and characterization of a luminal cholecystokinin-releasing factor from rat intestinal secretion. Proceedings of the National Academy of Science USA 93 , 4415-4420.

Sternini C, Wong H, Pham T, De Giorgio R, Miller LJ, Kuntz SM, Reeve JR, Walsh JH \& Raybould HE (1999) Expression of cholecystokinin A receptors in neurons innervating the rat stomach and intestine. Gastroenterology 117, 1136-1146.

Su SF, Amidon GL \& Lee HJ (2002) Intestinal metabolism and absorption of cholecystokinin analogs in rats. Biochemical and Biophysical Research Communications 292, 632-638.

Sun G, Chang TM, Xue W, Wey JFY, Lee KY \& Chey WY (1992) Release of cholecystokinin and secretin by sodium oleate in dogs: molecular form and bioactivity. American Journal of Physiology 262, G35-G43.

Takiguchi S, Takata Y, Funakoshi A, Miyasaka K, Kataoka K, Fujimura Y, Goto T \& Kono A (1997) Disrupted cholecystokinin type-A receptor (CCKAR) gene in OLETF rats. Gene 197, $169-175$.

Tang C, Biemond I \& Lamers CBHW (1996) Cholecystokinin receptors in human pancreas and gallbladder muscle: a comparative study. Gastroenterology 111, 1621-1626.

Tani S, Suzuki T, Kano S, Tanaka T, Sunaga K, Morishige R \& Tsuda T (2002) Mechanisms of gastric mucus secretion from cultured rat gastric epithelial cells induced by carbachol, 
cholecystokinin octapeptide, secretin and prostaglandin E2. Bulletin of Biology and Pharmacology 25, 14-18.

Tatemoto K, Jornvall H, Siimesmaa S, Hallden G \& Mutt V (1984) Isolation and characterization of cholecystokinin-58 (CCK-58) from porcine brain. FEBS Letters 174, 289-293.

Thimister PW, Hopman WP, van Roermund RF, Willems HL, Rosenbusch G, Woestenborghs R \& Jansen JB (1997) Inhibition of pancreaticobiliary secretion by loperamide in humans. Hepatology 26, 256-261.

Thomas RP, Hellmich MR, Townsend CM Jr \& Evers BM (2003) Role of gastrointestinal hormones in the proliferation of normal and neoplastic tissues. Endocrine Reviews 24, 571-599.

Thompson JC, Greeley GH, Reyford PL \& Townsend CM (1987) Gastrointestinal Endocrinology. New York: McGraw-Hill.

Thompson JC \& Marx M (1984) Gastrointestinal hormones. In Current Problems in Surgery, pp. 1-80 [MM Ravitch, editor]. Chicago: Year Book Medical Publishers.

Toullec R, Chayvialle JA, Guilloteau P \& Bernard C (1992) Earlylife patterns of plasma gut regulatory peptide levels in calves. Effects of age, weaning and feeding. Comparative Biochemistry and Physiolology 102A, 203-209.

Trulsson LM, Gasslander T, Sundqvist T \& Svanvik J (2002) The influence of nitric oxide on basal and cholecystokinin-8-induced proliferation and apoptosis in the rat pancreas. Regulatory Peptides 106, 97-104.

Trulsson LM, Svanvik J, Permert J \& Gasslander T (2001) Cholecystokinin octapeptide induces both proliferation and apoptosis in the rat pancreas. Regulatory Peptides 98, 41-48.

Tsunoda Y, Yao H, Park J \& Owyang C (2003) Cholecystokinin synthesizes and secretes leptin in isolated canine gastric chief cells. Biochemical and Biophysical Research Communications 310, 681-684.

van der Schaar PJ, Bremer Y, Lamers CBHW \& Masclee AAM (2001) Role of cholecystokinin in relaxation of the proximal stomach. Scandinavian Journal of Gastroenterology 36, 361-366.

Vanhoutte PM, Humphrey PP \& Spedding M (1996) $\mathrm{X}$. International Union of Pharmacology recommendations for nomenclature of new receptor subtypes. Pharmacological Reviews 48, 1-2.

Varga G, Balint A, Burghardt B \& D'Amato M (2004) Involvement of endogenous $\mathrm{CCK}$ and $\mathrm{CCK}_{1}$ receptors in colonic motor function. British Journal of Pharmacology 141, 1275-1284.

Varner AA, Modilin IM \& Walsh JH (1981) High potency of bombesin for stimulation of human gastrin release and gastric acid secretion. Regulatory Peptides 1, 289-296.

Varro A \& Ardill JE (2003) Gastrin: an analytical review. Annals of Clinical Biochemistry 40, 472-480.

Verkijk M, Gielkens HA, Lamers CB \& Masclee AA (1998) Effect of gastrin on antroduodenal motility: role of intraluminal acidity. American Journal of Physiology 275, G1209-G1216.

Von Schrenck T, Ahrens M, de Weerth A, et al. (2000) $\mathrm{CCKB} /$ gastrin receptors mediate changes in sodium and potassium absorption in the isolated perfused rat kidney. Kidney International 58, 995-1003.

Walsh JH (1994) Gastrin. In Gut Peptides: Biochemistry and Physiology, pp. 75-121 [JH Walsh and GF Dockray, editors]. New York: Raven Press.

Walsh JH, Debas HAT \& Grossman MI (1974) Pure human big gastrin. Immunochemical properties, disappearance half time, and acid-stimulating action in dogs. Journal of Clinical Investigation 54, 477-485.

Walsh JH \& Dockray GJ (1994) Gut Peptides. Biochemistry and Physiology. New York: Raven Press.

Wang G, Anini Y, Wei W, Qi X, O'Carroll AM, Mochizuki T, Wang HQ, Hellmich MR, Englander EW \& Greeley GH Jr (2004) Apelin, a new enteric peptide: localization in the gastrointestinal tract, ontogeny, and stimulation of gastric cell proliferation and of cholecystokinin secretion. Endocrinology 145, 1342-1348

Wang TC, Koh TJ, Varro A, Cahill RJ, Dangler CA, Fox JG \& Dockray GJ (1996) Processing and proliferative effects of human progastrin in transgenic mice. Journal of Clinical Investigation 98, 1918-1929.

Wang Y, Prpic V, Green GM, Reeve JR Jr \& Liddle RA (2002) Luminal CCK-releasing factor stimulates CCK release from human intestinal endocrine and STC-1 cells. American Journal of Physiology 282, G16-G22.

Wank SA (1995) Cholecystokinin receptors. American Journal of Physiology 269, G628-G646.

Wank SA (1998) G protein-coupled receptors in gastrointestinal physiology. I. CCK receptors: an exemplary family. American Journal of Physiology 274, G607-G613.

Wank SA, Pisegna JR \& de Weerth A (1992) Brain and gastrointestinal cholecystokinin receptor family: structure and functional expression. Proceedings of the National Academy of Science USA 89, 8691-8695.

Wank SA, Pisegna JR \& de Weerth A (1994) Cholecystokinin receptor family. Molecular cloning, structure, and functional expression in rat, guinea pig, and human. Annals of the New York Academy of Sciences 713, 49-66.

Watson SA \& Gilliam AD (2001) G17DT - a new weapon in the therapeutic armoury for gastrointestinal malignancy. Expert Opinion on Biological Therapy 1, 309-317.

West SD, Helmer KS, Chang LK, Cui Y, Greeley GH \& Mercer DW (2003) Cholecystokinin secretagogue-induced gastroprotection: role of nitric oxide and blood flow. American Journal of Physiology 284, G399-G410.

West SD \& Mercer DW (2004) Cholecystokinin-induced gastroprotection: a review of current protective mechanisms. Digestive Diseases and Sciences 49, 361-369.

West SD \& Mercer DW (2005) Bombesin-induced gastroprotection. Annals of Surgery 241, 227-231.

Whittle BJ (1993) Thirteenth Gaddum Memorial Lecture. Neuronal and endothelium-derived mediators in the modulation of the gastric microcirculation: integrity in the balance. British Journal of Pharmacology 110, 3-17.

Woltman T \& Reidelberger R (1999) Role of cholecystokinin in the anorexia produced by duodenal delivery of peptone in rats. American Journal of Physiology 276, R1701-R1709.

Wu CL, Hung CR, Chang FY, Pau KY, Wang JL \& Wang PS (2002) Involvement of cholecystokinin receptor in the inhibition of gastric emptying by oxytocin in male rats. Pflugers Archiv $\mathbf{4 4 5}$, $187-193$

Xiao R, Cui ZJ (2004) Mutual dependence of VIP/PACAP and CCK receptor signaling for a physiological role in duck exocrine pancreatic secretion. American Journal of Physiology 286, R189-R198.

Yamamoto M, Otani M, Jia DM, Fukumitsu K, Yoshikawa H, Akiyama T \& Otsuki M (2003) Differential mechanism and site of action of CCK on the pancreatic secretion and growth in rats. American Journal of Physiology 285, G681-G687.

Yassin RR (1999) Signaling pathways mediating gastrin's growthpromoting effects. Peptides 20, 885-898.

Yonekura S, Kitade K, Furukawa G, Takahashi K, Katsumata N, Katoh K \& Obara Y (2002) Effects of aging and weaning on mRNA expression of leptin and CCK receptors in the calf rumen and abomasum. Domestic Animal Endocrinology 22, 25-35.

Yu DH, Huang SC, Wank SA, Mantey S, Gardner JD \& Jensen RT (1990) Pancreatic receptors for cholecystokinin: evidence for three receptor classes. American Journal of Physiology 258, G86-G95.

Zabielski R, Dardillat C, Le Huerou-Luron I, Bernard C, Chayvialle JA \& Guilloteau P (1998a) Periodic fluctuations of 
gut regulatory peptides in phase with the duodenal migrating myoelectric complex in preruminant calves: effect of different sources of dietary protein. British Journal of Nutrition 79, 287-296.

Zabielski R, Kiela P, Barej W, Pierzynowski SG, Weström BR \& Karlsson BW (1991) Effects of CCK and VIP administered in the jugular vein or in the duodenal artery on pancreatic secretion in chronic experiments on pigs. Digestion 49, Suppl. 1, 60.

Zabielski R, Kiela P, Podgurniak P, Gregory PC \& Pierzynowski SG (1999) Cholecystokinin-like activity in the duodenal lumen of anaesthetized neonatal calves. Polish Journal of Veterinary Sciences 2, 13-17.

Zabielski R, Leśniewska V, Borlak J, Gregory PC, Kiela P, Pierzynowski SG \& Barej W (1998b) Effects of intraduodenal administration of tarazepide on pancreatic secretion and duodenal EMG in neonatal calves. Regulatory Peptides 78, $113-123$.

Zabielski R, Morisset J, Podgurniak P, Romé V, Biernat M, Bernard C, Chayvialle JA \& Guilloteau P (2002) Bovine pancreatic secretion in the first week of life; involvement of a CCK-A receptor. Regulatory Peptides 103, 93-104.

Zabielski R, Normand V, Romé V, Chayvialle JA, Wolinski J \& Guilloteau P (2004) The role of luminal gastrin in the regulation of pancreatic juice secretion in preruminant calves. Regulatory Peptides 119, 169-176.
Zabielski R, Onaga T, Mineo H, Kato S \& Pierzynowski SG (1995) Intraduodenal cholecystokinin octapeptide (CCK8) can stimulate pancreatic secretion in the calf. International Journal of Pancreatology 17, 271-278.

Zabielski R, Onaga T, Mineo H, Pierzynowski SG \& Kato S (1994) Local versus peripheral blood administration of cholecystokinin-8 and secretin on pancreatic secretion in calves. Experiencia Physiologica 79, 301-311.

Zavros Y \& Shulkes A (1997) Cholecystokinin (CCK) regulates somatostatin secretion through both the CCK-A and CCK$\mathrm{B} /$ gastrin receptors in sheep. Journal of Physiology 505, $811-821$

Zhang Y, Proenca R, Maffei M, Barone M, Leopold L \& Friedman JM (1994) Positioning cloning of the mouse ob gene and its human homologue. Nature 372, 425-432.

Zhou W, Povoski SP, Longnecker DS \& Bell RH Jr (1992) Novel expression of gastrin (cholecystokinin-B) receptors in azaserineinduced rat pancreatic carcinoma: receptor determination and characterization. Cancer Research 52, 6905-6911.

Zhu J, Han TQ, Chen S, Jiang Y \& Zhang SD (2005) Gallbladder motor function, plasma cholecystokinin and cholecystokinin receptor of gallbladder in cholesterol stone patients. World Journal of Gastroenterology 21, 1685-1689. 